Nevada

Environmental

Restoration

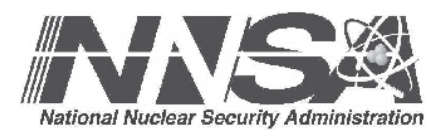

Project

Closure Report for

Corrective Action Unit 107:

Low Impact Soil Sites

Nevada Test Site, Nevada

Controlled Copy No.:

Revision: 0

June 2009

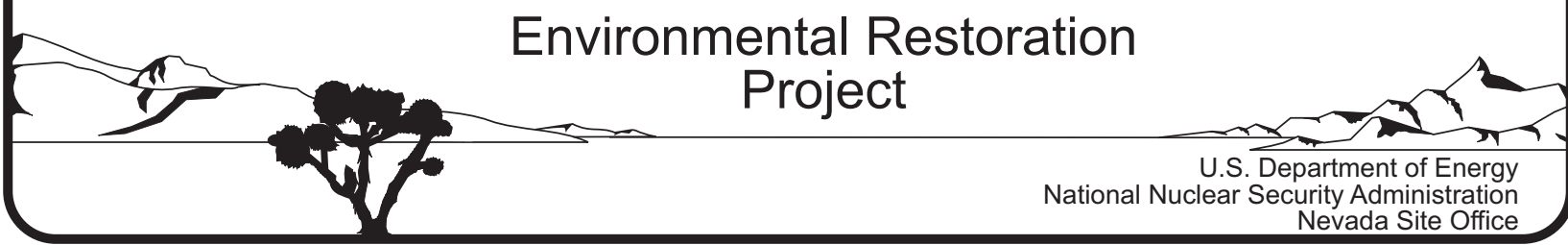




\section{DISCLAIMER}

Reference herein to any specific commercial product, process, or service by trade name, trademark, manufacturer, or otherwise, does not necessarily constitute or imply its endorsement, recommendation, or favoring by the United States Government or any agency thereof.

This report has been reproduced directly from the best available copy.

Available for sale to the public from:

U.S. Department of Commerce

National Technical Information Service

5285 Port Royal Road

Springfield, VA 22161-0002

Telephone: (800) 553-6847

Fax: (703) 605-6900

E-mail: orders@ntis.gov

Online ordering: http://www.ntis.gov/ordering.htm

Available electronically at http://www.osti.gov/bridge.

Available for a processing fee to the U.S. Department of Energy and its contractors, in paper, from:

U.S. Department of Energy

Office of Scientific and Technical Information

P.O. Box 62

Oak Ridge, TN 37831-0062

Telephone: (865) 576-8401

Fax: (865) 576-5728

E-mail: reports@adonis.osti.gov 


\title{
CLOSURE REPORT FOR CORRECTIVE ACTION UNIT 107: LOW IMPACT SOIL SITES, NEVADA TEST SITE, NEVADA
}

\author{
U.S. Department of Energy \\ National Nuclear Security Administration \\ Nevada Site Office \\ Las Vegas, Nevada
}

Controlled Copy No.

Revision: 0

June 2009 
THIS PAGE INTENTIONALLY LEFT BLANK 


\section{CLOSURE REPORT FOR CORRECTIVE ACTION UNIT 107: LOW IMPACT SOIL SITES, NEVADA TEST SITE, NEVADA}

\footnotetext{
Approved By: $\frac{/ \mathrm{S} / \mathrm{K} \text { Cabble }}{\text { Xate: } 6-z z-09}$

Kevin J. Cabble, Acting Federal Sub-Project Director

Soils Sub-Project

/S/K Boehlecke

Approved By:

Robert F. Boehlecke

Federal Project Director

Environmental Restoration Project
} 
THIS PAGE INTENTIONALLY LEFT BLANK 


\section{TABLE OF CONTENTS}

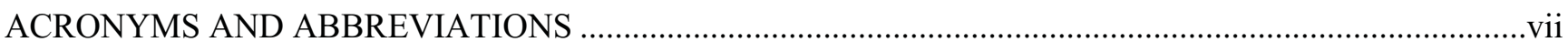

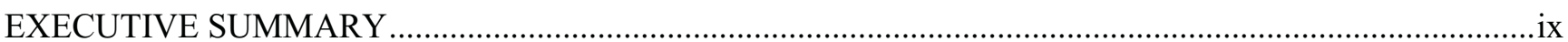

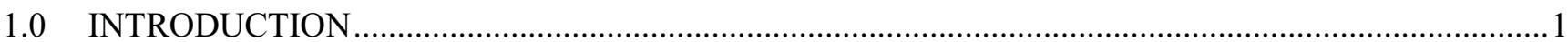

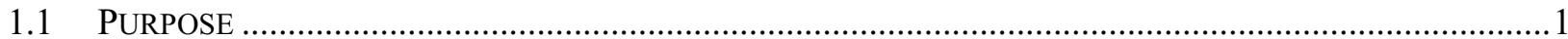

1.2 SCOPE.

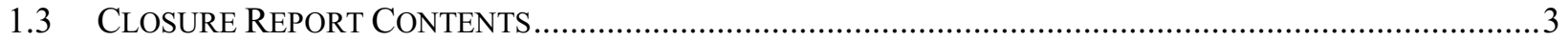

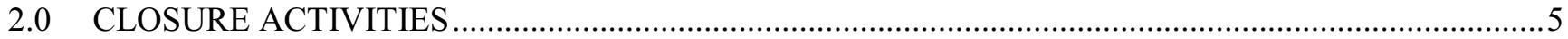

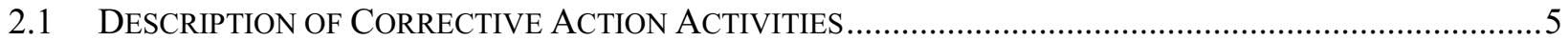

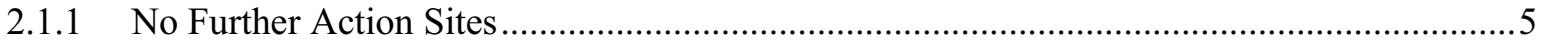

2.1.2 Closure in Place with Administrative Controls Sites ..........................................................6

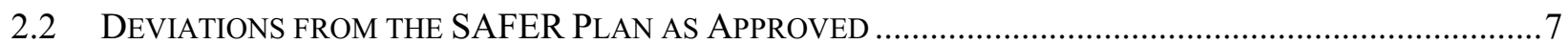

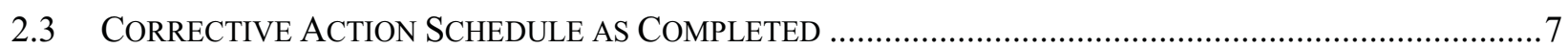

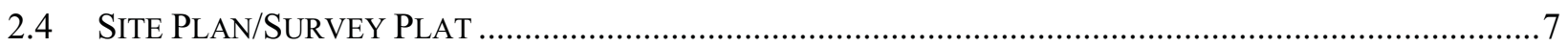

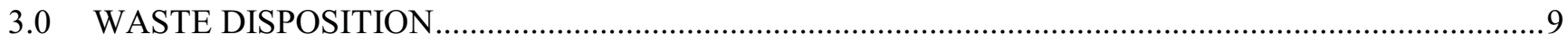

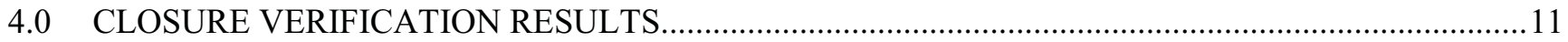

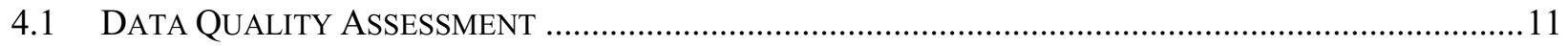

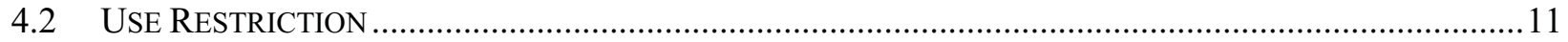

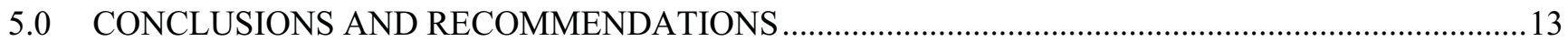

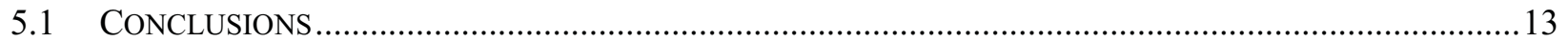

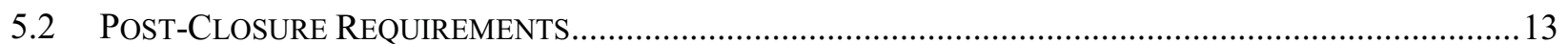

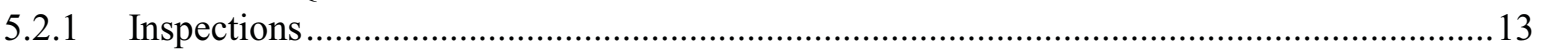

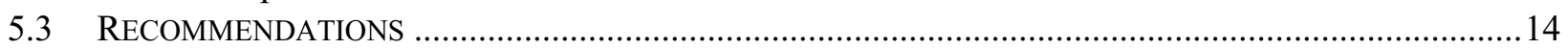

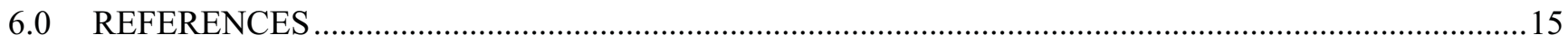

LIBRARY DISTRIBUTION LIST

\section{LIST OF FIGURES}

Figure 1. Corrective Action Unit 107 Site Location Map .........................................................2

\section{LIST OF TABLES}

Table 1. Summary of Corrective Action Unit 107 Closure Activities ................................... X

Table 2. Corrective Action Unit 107 Closure Activities Schedule ....................................... 7

\section{APPENDICES}

APPENDiX A. DATA QuALITY OBJECTIVES

APPENDIX B. USE RESTRICTION DOCUMENTATION

ApPEndix C. Site Closure Photographs 
CAU 107 Closure Report

Section: Table of Contents

Revision: 0

Date: June 2009

\section{THIS PAGE INTENTIONALLY LEFT BLANK}




\section{ACRONYMS AND ABBREVIATIONS}

BMP best management practice

CAS Corrective Action Site

CAU Corrective Action Unit

CFR Code of Federal Regulations

COC contaminant of concern

CR Closure Report

CSM conceptual site model

DQO data quality objective

FFACO Federal Facility Agreement and Consent Order

$\mathrm{mrem} / \mathrm{yr} \quad$ millirem(s) per year

NDEP Nevada Division of Environmental Protection

NNSA/NSO U.S. Department of Energy, National Nuclear Security Administration Nevada Site Office

NTS Nevada Test Site

RMA Radioactive Material Area

SAFER Streamlined Approach for Environmental Restoration

UR use restriction

URMA Underground Radioactive Material Area 
CAU 107 Closure Report

Section: Acronyms and Abbr.

Revision: 0

Date: June 2009

THIS PAGE INTENTIONALLY LEFT BLANK 


\section{EXECUTIVE SUMMARY}

Corrective Action Unit (CAU) 107 is identified in the Federal Facility Agreement and Consent Order (FFACO) as "Low Impact Soil Sites" and consists of the following 15 Corrective Action Sites (CASs), located in Areas 1, 2, 3, 4, 5, 9, 10, and 18 of the Nevada Test Site:

- CAS 01-23-02, Atmospheric Test Site - High Alt

- CAS 02-23-02, Contaminated Areas (2)

- CAS 02-23-03, Contaminated Berm

- CAS 02-23-10, Gourd-Amber Contamination Area

- CAS 02-23-11, Sappho Contamination Area

- CAS 02-23-12, Scuttle Contamination Area

- CAS 03-23-24, Seaweed B Contamination Area

- CAS 03-23-27, Adze Contamination Area

- CAS 03-23-28, Manzanas Contamination Area

- CAS 03-23-29, Truchas-Chamisal Contamination Area

- CAS 04-23-02, Atmospheric Test Site T4-a

- CAS 05-23-06, Atmospheric Test Site

- CAS 09-23-06, Mound of Contaminated Soil

- CAS 10-23-04, Atmospheric Test Site M-10

- CAS 18-23-02, U-18d Crater (Sulky)

Closure activities were conducted from February through April 2009 according to the FFACO (1996; as amended February 2008) and Revision 1 of the Streamlined Approach for Environmental Restoration Plan for CAU 107 (U.S. Department of Energy, National Nuclear Security Administration Nevada Site Office, 2009). The corrective action alternatives included No Further Action and Closure in Place with Administrative Controls. Closure activities are summarized in Table 1. 
CAU 107 Closure Report

Section: Executive Summary

Revision: 0

Date: June 2009

Table 1. Summary of Corrective ACtion Unit 107 Closure Activities

\begin{tabular}{|c|c|c|c|c|}
\hline CAS & CAS Name & Closure Method & $\mathrm{COC}$ & Closure Activities \\
\hline $01-23-02$ & $\begin{array}{l}\text { Atmospheric Test Site - } \\
\text { High Alt }\end{array}$ & No Further Action & None & $\begin{array}{l}\text { As a BMP, a site visit was conducted. } 10 \text { CFR } 835 \text { postings are not required at this } \\
\text { site. }\end{array}$ \\
\hline $02-23-02$ & Contaminated Areas (2) & No Further Action & None & $\begin{array}{l}\text { As a BMP, existing } 10 \text { CFR } 835 \text { URMA postings were inspected. Two radiological } \\
\text { warning signs were reattached to the fence. }\end{array}$ \\
\hline $02-23-03$ & Contaminated Berm & No Further Action & None & $\begin{array}{l}\text { As a BMP, existing } 10 \text { CFR } 835 \text { URMA postings were inspected and verified to be in } \\
\text { good condition. }\end{array}$ \\
\hline $02-23-10$ & $\begin{array}{l}\text { Gourd-Amber } \\
\text { Contamination Area }\end{array}$ & No Further Action & None & $\begin{array}{l}\text { As a BMP, a site visit was conducted. } 10 \text { CFR } 835 \text { postings are not required at this } \\
\text { site. }\end{array}$ \\
\hline $02-23-11$ & $\begin{array}{l}\text { Sappho Contamination } \\
\text { Area }\end{array}$ & No Further Action & None & $\begin{array}{l}\text { As a BMP, existing } 10 \text { CFR } 835 \text { URMA postings were inspected and verified to be in } \\
\text { good condition. }\end{array}$ \\
\hline $02-23-12$ & $\begin{array}{l}\text { Scuttle Contamination } \\
\text { Area }\end{array}$ & No Further Action & None & $\begin{array}{l}\text { As a BMP, existing } 10 \text { CFR } 835 \text { URMA postings were inspected and verified to be in } \\
\text { good condition. }\end{array}$ \\
\hline $03-23-24$ & $\begin{array}{l}\text { Seaweed B } \\
\text { Contamination Area }\end{array}$ & No Further Action & None & $\begin{array}{l}\text { As a BMP, existing } 10 \text { CFR } 835 \text { URMA postings were inspected. One radiological } \\
\text { warning sign was reattached to the fence. }\end{array}$ \\
\hline $03-23-27$ & $\begin{array}{l}\text { Adze Contamination } \\
\text { Area }\end{array}$ & No Further Action & None & $\begin{array}{l}\text { As a BMP, existing } 10 \text { CFR } 835 \text { URMA postings were inspected and verified to be in } \\
\text { good condition. }\end{array}$ \\
\hline $03-23-28$ & $\begin{array}{l}\text { Manzanas } \\
\text { Contamination Area }\end{array}$ & No Further Action & None & $\begin{array}{l}\text { As a BMP, existing } 10 \text { CFR } 835 \text { URMA postings were inspected and verified to be in } \\
\text { good condition. }\end{array}$ \\
\hline $03-23-29$ & $\begin{array}{l}\text { Truchas-Chamisal } \\
\text { Contamination Area }\end{array}$ & $\begin{array}{l}\text { Closure in Place with } \\
\text { Administrative Controls }\end{array}$ & Radionuclides & $\begin{array}{l}\text { UR warning signs were installed. As a BMP, existing } 10 \text { CFR } 835 \text { URMA postings } \\
\text { were inspected and verified to be in good condition. }\end{array}$ \\
\hline $04-23-02$ & $\begin{array}{l}\text { Atmospheric Test Site } \\
\text { T4-a }\end{array}$ & No Further Action & None & $\begin{array}{l}\text { As a BMP, a site visit was conducted. } 10 \text { CFR } 835 \text { postings are not required at this } \\
\text { site. }\end{array}$ \\
\hline $05-23-06$ & Atmospheric Test Site & No Further Action & None & $\begin{array}{l}\text { As a BMP, existing } 10 \text { CFR } 835 \text { RMA postings were inspected and verified to be in } \\
\text { good condition. }\end{array}$ \\
\hline $09-23-06$ & $\begin{array}{l}\text { Mound of } \\
\text { Contaminated Soil }\end{array}$ & No Further Action & None & $\begin{array}{l}\text { As a BMP, existing } 10 \text { CFR } 835 \text { URMA postings were inspected and verified to be in } \\
\text { good condition. }\end{array}$ \\
\hline $10-23-04$ & $\begin{array}{l}\text { Atmospheric Test Site } \\
\text { M-10 }\end{array}$ & No Further Action & None & $\begin{array}{l}\text { As a BMP, a site visit was conducted. } 10 \text { CFR } 835 \text { postings are not required at this } \\
\text { site. }\end{array}$ \\
\hline $18-23-02$ & U-18d Crater (Sulky) & $\begin{array}{l}\text { Closure in Place with } \\
\text { Administrative Controls }\end{array}$ & Radionuclides & $\begin{array}{l}\text { UR warning signs were installed. As a BMP, existing } 10 \text { CFR } 835 \text { RMA postings } \\
\text { were inspected and verified to be in good condition. }\end{array}$ \\
\hline
\end{tabular}

BMP: best management practice CAS: Corrective Action Site

CFR: Code of Federal Regulations
COC: contaminant of concern RMA: Radioactive Material Area

UR: use restriction
URMA: Underground Radioactive Material Area 


\subsection{INTRODUCTION}

This Closure Report (CR) documents closure activities for Corrective Action Unit (CAU) 107, "Low Impact Soil Sites," according to the Federal Facility Agreement and Consent Order (FFACO) (1996; as amended February 2008) and Revision 1 of the Streamlined Approach for Environmental Restoration (SAFER) Plan for CAU 107 (U.S. Department of Energy, National Nuclear Security Administration Nevada Site Office [NNSA/NSO], 2009). CAU 107 consists of the following 15 Corrective Action Sites (CASs), located in Areas 1, 2, 3, 4, 5, 9, 10, and 18 of the Nevada Test Site (NTS) (Figure 1):

- CAS 01-23-02, Atmospheric Test Site - High Alt

- CAS 02-23-02, Contaminated Areas (2)

- CAS 02-23-03, Contaminated Berm

- CAS 02-23-10, Gourd-Amber Contamination Area

- CAS 02-23-11, Sappho Contamination Area

- CAS 02-23-12, Scuttle Contamination Area

- CAS 03-23-24, Seaweed B Contamination Area

- CAS 03-23-27, Adze Contamination Area

- CAS 03-23-28, Manzanas Contamination Area

- CAS 03-23-29, Truchas-Chamisal Contamination Area

- CAS 04-23-02, Atmospheric Test Site T4-a

- CAS 05-23-06, Atmospheric Test Site

- CAS 09-23-06, Mound of Contaminated Soil

- CAS 10-23-04, Atmospheric Test Site M-10

- CAS 18-23-02, U-18d Crater (Sulky)

\subsection{PuRPoSe}

CAU 107, "Low Impact Soil Sites," consists of 15 CASs in Areas 1, 2, 3, 4, 5, 9, 10, and 18 of the NTS. The closure alternatives included No Further Action and Closure in Place with Administrative Controls. This CR provides a summary of completed closure activities. 


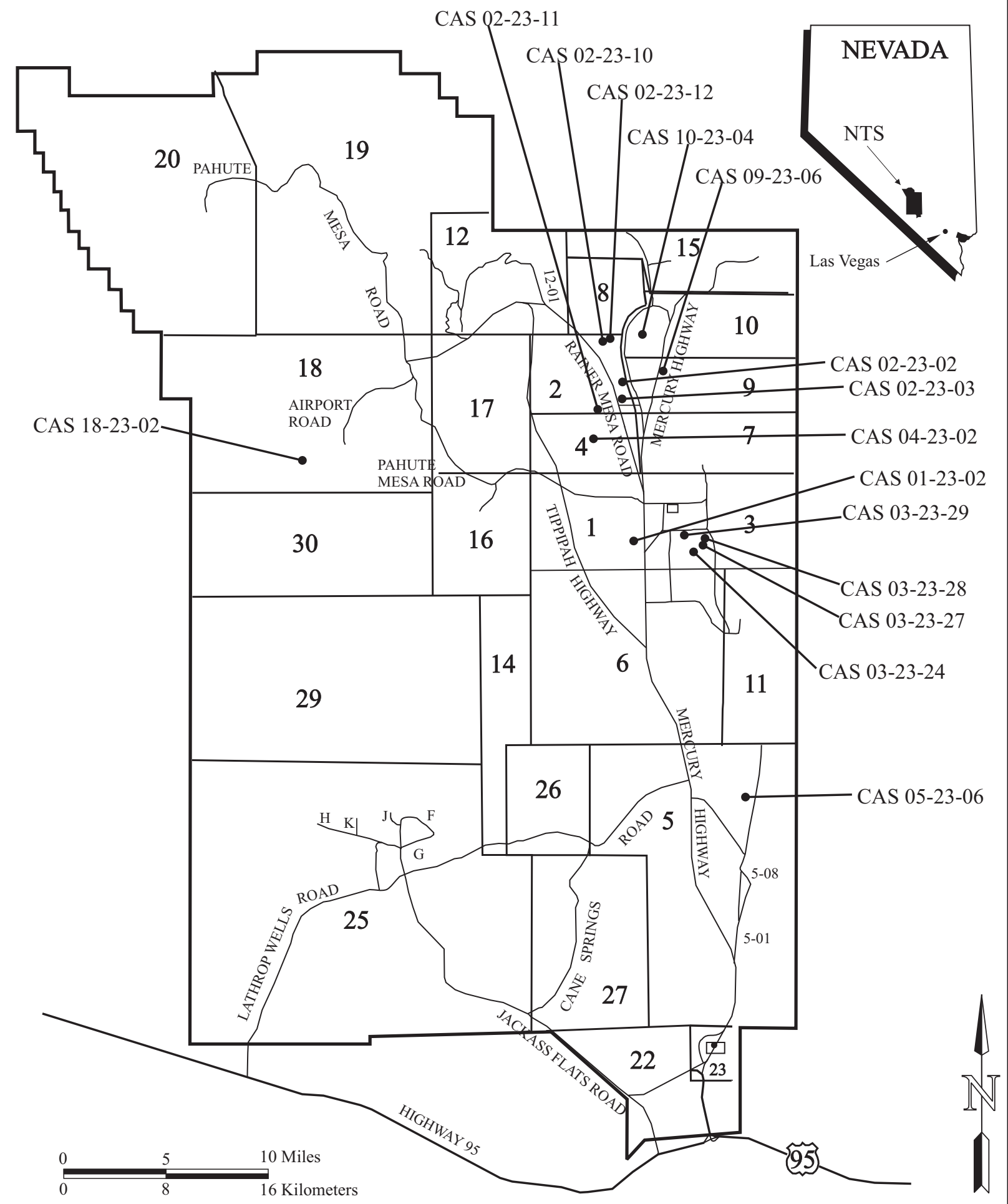

FIGURE 1

CORRECTIVE ACTION UNIT 107 Site LOCATION MAP 


\subsection{SCOPE}

No further action was required at 13 of the $15 \mathrm{CASs}$; however, as a best management practice (BMP), site visits were conducted to document site conditions. Several of the sites require postings for compliance with Title 10 Code of Federal Regulations (CFR) Part 835, "Occupational Radiation Protection" (CFR, 1993). At these sites, as a BMP, the existing postings were inspected and repaired if needed. The following CASs required no further action:

- CAS 01-23-02, Atmospheric Test Site - High Alt

- CAS 02-23-02, Contaminated Areas (2)

- CAS 02-23-03, Contaminated Berm

- CAS 02-23-10, Gourd-Amber Contamination Area

- CAS 02-23-11, Sappho Contamination Area

- CAS 02-23-12, Scuttle Contamination Area

- CAS 03-23-24, Seaweed B Contamination Area

- CAS 03-23-27, Adze Contamination Area

- CAS 03-23-28, Manzanas Contamination Area

- CAS 04-23-02, Atmospheric Test Site T4-a

- CAS 05-23-06, Atmospheric Test Site

- CAS 09-23-06, Mound of Contaminated Soil

- CAS 10-23-04, Atmospheric Test Site M-10

The following CASs were closed in place with administrative controls; use restriction (UR) warning signs were posted; and as a BMP, the existing 10 CFR 835 postings were inspected and verified to be in good condition:

- CAS 03-23-29, Truchas-Chamisal Contamination Area

- CAS 18-23-02, U-18d Crater (Sulky)

\subsection{Closure Report Contents}

This CR includes the following sections:

- Section 1.0 - Introduction

- Section 2.0 - Closure Activities

- Section 3.0 - Waste Disposition

- Section 4.0-Closure Verification Results

- Section 5.0 - Conclusions and Recommendations

- Section 6.0 - References

- Appendix A - Data Quality Objectives 
- Appendix B - Use Restriction Documentation

- Appendix C - Site Closure Photographs

- Library Distribution List

Data quality objectives (DQOs) were developed for site characterization of CAU 107 and presented in Section 3.0 of Revision 1 of the SAFER Plan for CAU 107 (NNSA/NSO, 2009). The DQOs are included as Appendix A of this report.

Conceptual site models (CSMs) were developed based on process knowledge and historical information. The CSM for 13 of the 15 CASs is that a distinct, measurable release of radionuclides to the soils has not occurred as a result of the associated tests, and there is no credible exposure pathway that could cause an NTS worker to receive a dose greater than 25 millirems per year (mrem/yr). Data are adequate to support a closure option of No Further Action for these sites.

Historical evidence indicates that there is limited contamination within the potential crater area of the TRUCHAS-CHAMISAL detonation associated with CAS 03-23-29. Historical evidence also indicates that there may be limited contamination present at the SULKY site associated with CAS 18-23-02. Data are adequate to support a closure option of Closure in Place with Administrative Controls at these two CASs. 


\subsection{CLOSURE ACTIVITIES}

This section describes the closure activities completed for CAU 107, deviations from the SAFER Plan, and the schedule of completed activities.

\subsection{Description of Corrective ACTION ACTIVITIES}

The following sections describe the closure activities completed for CAU 107.

\subsubsection{No Further Action Sites}

For 13 of the $15 \mathrm{CASs}$, operational history and historical data indicate that a distinct, measurable release of radionuclides to the soils has not occurred as a result of the associated tests, and there is no credible exposure pathway that could cause an NTS worker to receive a dose greater than $25 \mathrm{mrem} / \mathrm{yr}$. No further action was required; however, as a BMP, site visits were conducted to document site conditions and verify that no additional environmental hazards are present. Photographs of the sites were taken during the site visits and are included in Appendix C. At the sites that require radiological postings to satisfy the requirements of $10 \mathrm{CFR} 835$, the current postings were inspected and repaired if needed. The following BMPs were conducted at the sites that required no further action:

- At CAS 01-23-02, Atmospheric Test Site - High Alt, a site visit was conducted, and photographs were taken to document site conditions. 10 CFR 835 postings are not required at this site, and no additional environmental hazards were observed during the site visit.

- At CAS 02-23-02, Contaminated Areas (2), a site visit was conducted, and photographs were taken to document site conditions. The existing 10 CFR 835 Underground Radioactive Material Area (URMA) postings were inspected, and two signs were reattached to the fence. No additional environmental hazards were observed during the site visit.

- At CAS 02-23-03, Contaminated Berm, a site visit was conducted, and photographs were taken to document site conditions. The existing 10 CFR 835 URMA postings were inspected and verified to be in good condition. No additional environmental hazards were observed during the site visit.

- At CAS 02-23-10, Gourd-Amber Contamination Area, a site visit was conducted, and photographs were taken to document site conditions. 10 CFR 835 postings are not required at this site, and no additional environmental hazards were observed during the site visit.

- At CAS 02-23-11, Sappho Contamination Area, a site visit was conducted, and photographs were taken to document site conditions. The existing 10 CFR 835 URMA postings were inspected and verified to be in good condition. No additional environmental hazards were observed during the site visit.

- At CAS 02-23-12, Scuttle Contamination Area, a site visit was conducted, and photographs were taken to document site conditions. The existing 10 CFR 835 URMA postings were inspected and verified to be in good condition. No additional environmental hazards were observed during the site visit.

- At CAS 03-23-24, Seaweed B Contamination Area, a site visit was conducted, and photographs were taken to document site conditions. The existing 10 CFR 835 URMA postings were inspected, and one sign was reattached to the fence. No additional environmental hazards were observed during the site visit. 
- At CAS 03-23-27, Adze Contamination Area, a site visit was conducted, and photographs were taken to document site conditions. The existing 10 CFR 835 URMA postings were inspected and verified to be in good condition. No additional environmental hazards were observed during the site visit.

- At CAS 03-23-28, Manzanas Contamination Area, a site visit was conducted, and photographs were taken to document site conditions. The existing 10 CFR 835 URMA postings were inspected and verified to be in good condition. No additional environmental hazards were observed during the site visit.

- At CAS 04-23-02, Atmospheric Test Site T4-a, a site visit was conducted, and photographs were taken to document site conditions. 10 CFR 835 postings are not required at this site, and no additional environmental hazards were observed during the site visit.

- At CAS 05-23-06, Atmospheric Test Site, a site visit was conducted, and photographs were taken to document site conditions. The existing 10 CFR 835 Radioactive Material Area (RMA) postings were inspected and verified to be in good condition. No additional environmental hazards were observed during the site visit.

- At CAS 09-23-06, Mound of Contaminated Soil, a site visit was conducted, and photographs were taken to document site conditions. The existing 10 CFR 835 URMA postings were inspected and verified to be in good condition. No additional environmental hazards were observed during the site visit.

- At CAS 10-23-04, Atmospheric Test Site M-10, a site visit was conducted, and photographs were taken to document site conditions. 10 CFR 835 postings are not required at this site, and no additional environmental hazards were observed during the site visit.

\subsubsection{Closure in Place with Administrative Controls Sites}

The following CASs were closed in place with administrative controls:

- CAS 03-23-29, Truchas-Chamisal Contamination Area

- CAS 18-23-02, U-18d Crater (Sulky)

Contaminants of potential concern were identified in historical information about these sites. A post-test radiological survey identified low levels of alpha contamination on a concrete pad at CAS 03-23-29, and particulate releases of radionuclides were identified at CAS 18-23-02 in the historical document Radiological Effluents Released from U.S. Continental Tests, 1961 through 1992 (U.S. Department of Energy, Nevada Operations Office, 1996).

At CAS 03-23-29, UR warning signs were posted according to the FFACO UR posting guidance (FFACO, 2003) outside the existing fence that delineates the radiologically controlled area. As a BMP, the existing 10 CFR 835 URMA postings were inspected and verified to be in good condition. No additional environmental hazards were observed at the site.

At CAS 18-23-02, UR warning signs were posted according to the FFACO UR posting guidance (FFACO, 2003) outside the existing fence that delineates the radiologically controlled area. As a BMP, the existing 10 CFR 835 RMA postings were inspected and verified to be in good condition. No additional environmental hazards were observed at the site. 


\subsection{DEViations FROM THE SAFER Plan AS APPROVED}

Deviations from the SAFER Plan (NNSA/NSO, 2009) were not necessary.

\subsection{Corrective ACtion Schedule as Completed}

Closure activities were completed in February and April 2009. Details of the schedule are provided in Table 2 .

\section{TAble 2. Corrective ACtion Unit 107 Closure Activities Schedule}

\begin{tabular}{|l|c|c|}
\hline \multicolumn{1}{|c|}{ ACTIVITY } & START DATE & END DATE \\
\hline \hline Conduct site visits & February 17, 2009 & February 17, 2009 \\
\hline Reattach radiological postings & February 23, 2009 & February 23, 2009 \\
\hline Install UR warning signs & April 16, 2009 & April 20, 2009 \\
\hline
\end{tabular}

UR: use restriction

\subsection{Site Plan/Survey Plat}

As-built drawings were not required for CAU 107 closure activities. 
CAU 107 Closure Report

Section: Closure Activities

Revision: 0

Date: June 2009

THIS PAGE INTENTIONALLY LEFT BLANK 


\subsection{WASTE DISPOSITION}

No waste was generated during closure of CAU 107. 
CAU 107 Closure Report

Section: Waste Disposition

Revision: 0

Date: June 2009

THIS PAGE INTENTIONALLY LEFT BLANK 


\subsection{CLOSURE VERIFICATION RESULTS}

Site closure was verified by visual observations and photographs. Photographs documenting site conditions are included as Appendix C.

\subsection{Data Quality Assessment}

Samples were not collected for closure of CAU 107.

\subsection{USE RESTRICTION}

A UR has been implemented for assumed radioactive contamination that could cause an NTS worker to receive a dose greater than $25 \mathrm{mrem} / \mathrm{yr}$ at the following CASs:

- CAS 03-23-29, Truchas-Chamisal Contamination Area

- CAS 18-23-02, U-18d Crater (Sulky)

At CAS 03-23-29, Truchas-Chamisal Contamination Area, historical evidence indicates that there is limited contamination on the concrete pad and sheave located within the fenced URMA. Based on radiological surveys performed for the Nevada Test Site Contaminated Land Areas Report (Bechtel Nevada, 2000), contamination is not migrating outside the fenced area; therefore, the UR was established at the fence. Additional information can be found in Section 2.12.3.2 of Revision 1 of the SAFER Plan for CAU 107 (NNSA/NSO, 2009).

At CAS 18-23-02, U-18d Crater (Sulky), historical evidence indicates that there may be limited contamination within the fenced RMA; however, representative sampling of this site would be difficult to achieve due to the nature of the large rubble pile created by the test. In addition, if contamination is present, it is likely on the large rubble, not in the soils. Based on radiological surveys performed for the Nevada Test Site Contaminated Land Areas Report (Bechtel Nevada, 2000), contamination is not migrating outside the fenced area; therefore, the UR was established at the fence. Additional information can be found in Section 2.17.3.2 of Revision 1 of the SAFER Plan for CAU 107 (NNSA/NSO, 2009).

The future use of the UR areas is restricted from any activity that may alter or modify the containment controls, unless appropriate concurrence is obtained in advance. UR warning signs were posted to warn against intrusive activity according to the FFACO UR posting guidance (FFACO, 2003). Annual site inspections will be required to ensure that the signs are intact and legible and that the UR is maintained. Details on the post-closure requirements are included in Section 5.2. The CAU Use Restriction Information forms and figures showing the locations of the surveyed points delineating the UR area are included in Appendix B. 
CAU 107 Closure Report

Section: Closure Verification

Revision: 0

Date: June 2009

THIS PAGE INTENTIONALLY LEFT BLANK 


\subsection{CONCLUSIONS AND RECOMMENDATIONS}

\subsection{Conclusions}

At the following CASs, no further action was required; however, as a BMP, site visits were conducted to document site conditions and verify postings, as applicable:

- CAS 01-23-02, Atmospheric Test Site - High Alt

- CAS 02-23-02, Contaminated Areas (2)

- CAS 02-23-03, Contaminated Berm

- CAS 02-23-10, Gourd-Amber Contamination Area

- CAS 02-23-11, Sappho Contamination Area

- CAS 02-23-12, Scuttle Contamination Area

- CAS 03-23-24, Seaweed B Contamination Area

- CAS 03-23-27, Adze Contamination Area

- CAS 03-23-28, Manzanas Contamination Area

- CAS 04-23-02, Atmospheric Test Site T4-a

- CAS 05-23-06, Atmospheric Test Site

- CAS 09-23-06, Mound of Contaminated Soil

- CAS 10-23-04, Atmospheric Test Site M-10

At the following CASs, UR warning signs were posted, and a UR was implemented:

- CAS 03-23-29, Truchas-Chamisal Contamination Area

- CAS 18-23-02, U-18d Crater (Sulky)

\subsection{Post-Closure ReQuirements}

\subsubsection{Inspections}

The following CASs require post-closure inspections:

- CAS 03-23-29, Truchas-Chamisal Contamination Area

- CAS 18-23-02, U-18d Crater (Sulky)

Radiological contamination is assumed to be present based on historical information about the sites. Inspections will be performed annually to verify that the UR warning signs are in place and legible and that the URs are maintained. The interiors of the UR areas will be inspected to confirm there have been no disturbances to the areas. Maintenance or repair needs that are identified, such as sign or post repair, will be completed prior to the following inspection and documented in writing at the time the work is done. Inspection results will be documented in the 
annual combined NTS post-closure letter report. The report will include a discussion of observations and will describe any maintenance activities performed since the last inspection. Copies of the inspection checklists will be provided, and the field notes will be maintained in the project files. The letter report will be submitted to the Nevada Division of Environmental Protection (NDEP).

\subsection{RECOMMENDATIONS}

Since closure activities for CAU 107 have been completed following the NDEP-approved SAFER Plan (NNSA/NSO, 2009) as documented in this report, NNSA/NSO requests the following:

- A Notice of Completion be provided by NDEP to NNSA/NSO for closure of CAU 107.

- The transfer of CAU 107 from Appendix III to Appendix IV, Closed Corrective Action Units, of the FFACO (1996; as amended February 2008). 


\subsection{REFERENCES}

Bechtel Nevada, 2000. Nevada Test Site Contaminated Land Areas Report, Volume I. DOE/NV/11718--324. Prepared for the U.S. Department of Energy, Nevada Operations Office. Las Vegas, NV.

CFR, see Code of Federal Regulations.

Code of Federal Regulations, Title 10, Part 835, “Occupational Radiation Protection,” 1993.

Federal Facility Agreement and Consent Order, 1996 (as amended February 2008). Agreed to by the State of Nevada; U.S. Department of Energy, Environmental Management; U.S. Department of Defense; and U.S. Department of Energy, Legacy Management.

Federal Facility Agreement and Consent Order, 2003. Use Restriction Posting Guidance.

FFACO, see Federal Facility Agreement and Consent Order.

NNSA/NSO, see U.S. Department of Energy, National Nuclear Security Administration Nevada Site Office.

U.S. Department of Energy, National Nuclear Security Administration Nevada Site Office, 2009. Streamlined Approach for Environmental Restoration Plan for Corrective Action Unit 107: Low Impact Soil Sites, Nevada Test Site, Nevada. DOE/NV--1295-REV.1. Las Vegas, NV.

U.S. Department of Energy, Nevada Operations Office, 1996. Radiological Effluents Released from U.S. Continental Tests, 1961 through 1992. Prepared by Bechtel Nevada. Las Vegas, NV. 
CAU 107 Closure Report

Section: References

Revision: 0

Date: June 2009

\section{THIS PAGE INTENTIONALLY LEFT BLANK}




\section{APPENDIX A*}

\section{DATA QUALITY OBJECTIVES}

* As presented and published in Section 3.0 of the approved Streamlined Approach for Environmental Restoration Plan for Corrective Action Unit 107: Low Impact Soil Sites, Nevada Test Site, Nevada, 2009, DOE/NV--1295-REV.1. Las Vegas, NV. 
CAU 107 Closure Report

Section: Appendix A

Revision: 0

Date: June 2009

THIS PAGE INTENTIONALLY LEFT BLANK 


\subsection{DATA QUALITY OBJECTIVES}

The DQO process is a seven-step systematic planning method based on the scientific method. The information presented in this document is based on historical data generated from preliminary assessment activities for CAU 107. The DQOs were developed according to the EPA Guidance on Systematic Planning Using the Data Quality Objectives Process (EPA, 2006). The steps systematically build on the data acquired during preliminary assessment work and background research.

\subsection{SUMMARY OF DQO ANALYSIS}

\subsubsection{State The Problem (SteP 1)}

Step 1 of the DQO process describes the problem to be studied and develops a CSM to gain a sufficient understanding in defining the problem.

\subsubsection{Problem Statement}

The problem statement for CAU 107 is "Conceptual corrective actions have been clearly identified based on historical data and background information. Are the sites sufficiently characterized to support closure through no further action and/or administrative controls?"

\subsubsection{Conceptual Site Model}

The CSM is used to organize and communicate information about site characteristics. It reflects the best interpretation of available information. The CSM is based on historical documentation, personnel interviews, site process knowledge, site visits, photographs, engineering drawings, field screening, and analytical results. The CSM describes the most probable scenario for current conditions at the site and defines the assumptions that are the basis for choosing a conceptual corrective action alternative.

The sites fall into the following categories:

- Category A: Sites associated with atmospheric tests with no confirmed release to surface soils

- CAS 01-23-02, Atmospheric Test Site - High Alt

○ CAS 05-23-06, Atmospheric Test Site

○ CAS 10-23-04, Atmospheric Test Site M-10

- Category B: Sites associated with underground tests and detonations with no confirmed release to surface soils

○ CAS 02-23-02, Contaminated Areas (2)

- CAS 02-23-10, Gourd-Amber Contamination Area

- CAS 02-23-11, Sappho Contamination Area

- CAS 02-23-12, Scuttle Contamination Area

- CAS 03-23-24, Seaweed B Contamination Area

- CAS 03-23-28, Manzanas Contamination Area

○ CAS 09-23-06, Mound of Contaminated Soil 
- Category C: Sites associated with atmospheric or underground tests and detonations with possible release to surface soils

- CAS 02-23-03, Contaminated Berm

- CAS 03-23-27, Adze Contamination Area

- CAS 03-23-29, Truchas-Chamisal Contamination Area

○ CAS 04-23-02, Atmospheric Test Site T4-a

○ CAS 18-23-02, U-18d Crater (Sulky)

\subsubsection{IDENTIFY THE GOAL OF THE STUDY (STEP 2)}

Step 2 of the DQO process identifies the questions the study will attempt to resolve and what actions may result. The goal of the study is to answer the following questions satisfactorily:

1. Does historical information indicate that a release to ground surface soils occurred as a result of the associated detonation?

2. If so, is the soil impacted with contamination levels that exceed action levels?

3. If so, do the risks to personnel and the environment justify a corrective action, or are the current 10 CFR 835, "Occupational Radiation Protection," compliant controls adequate for this purpose?

\subsubsection{IDENTIFY INFORMATION INPUTS (STEP 3)}

Step 3 of the DQO process identifies the information needed to address the goals of the study.

\subsubsection{Information Needs}

In order to determine if a distinct, measurable release to the surface soils resulting from historical operations occurred and, if so, to quantify that release, existing historical information must be evaluated using the following criteria:

- Documented process knowledge indicates a release to surface soils has not occurred.

- Tests were documented to be performed well above ground surface.

○ Documented releases were short-lived, gaseous radionuclides.

- Location and direction of plume deposition paths (or lack thereof) were recorded in post-test documentation.

- Process knowledge and multiple, semi-quantitative data sets are in agreement with each other.

- Aerial survey data provide 100-percent coverage of areas.

- RIDP data were collected from areas most likely to be contaminated on a statistically based grid.

- Contaminated Lands Report Survey data were collected from areas most likely to be contaminated.

- Soil sampling data were collected under an approved CAIP from sites with similar CSMs.

\subsubsection{Sources of Information}

Existing information, such as historical documentation, personnel interviews, site process knowledge, site visits, photographs, and previous field screening and analytical results, will be evaluated to determine if it satisfies the decisions. 


\section{Qualitative Data}

Qualitative data identify or describe the characteristics or components of the site. The quality assurance (QA)/quality control (QC) requirements are the least rigorous for qualitative data. This measurement of quality is typically assigned to historical information and data where QA/QC may be highly variable or not known. Professional judgment is often used to generate qualitative data. Visual observations made during field visits, process knowledge about the sites and the nature of the atmospheric tests, and historical records and interviews will be used to confirm the absence or presence of contamination.

\section{Semi-quantitative Data}

Semi-quantitative data indirectly measure the quantity or amount of a characteristic or component. Inferences are drawn about the quantity or amount of a characteristic or component because a correlation has been shown to exist between the indirect measurement and a quantitative measurement. QA/QC requirements on semi-quantitative collection and measurements are high but may not be as rigorous as for quantitative data. Previous data that have been collected, including 1994 aerial radiological survey results (Hendricks and Riedhauser, 1999), RIDP data (McArthur, 1991), dose rate measurements, FIDLER readings, removable alpha and beta/gamma measurements, walkover radiological survey results, and other data, will be evaluated. Some portions of these data sets may be considered quantitative.

\section{Quantitative Data}

Quantitative data measure the quantity or amount of a characteristic or component. These data require the highest level of QA/QC in collection and measurement systems because the intended use of the data is to resolve primary decisions and/or to verify that closure standards have been met. Laboratory analytical data are generally considered quantitative. For the sites where analytical data have been collected, these data will be evaluated to verify they meet the information needs and satisfy the criteria for the decision inputs. Portions of the RIDP data may qualify as quantitative. Soil sampling data were collected and analyzed under both a field and laboratory QA/QC program. In situ measurements that directly quantify gamma-emitting radionuclides should be considered quantitative if appropriately validated.

\subsubsection{Define The Boundaries OF THE STUdy (STEP 4)}

Step 4 of the DQO process defines target populations of interest, specifies spatial boundaries and time constraints, and determines practical constraints on data collection.

\subsubsection{Population of Interest}

The population of interest to resolve the decisions includes the spatial boundaries of the sites. The spatial boundaries of all sites are limited to the surface or near-surface radioactive contamination. This CAU contains several types of sites:

- Atmospheric tests with no distinct, operationally related contaminant plume (3 of 15 sites)

- Underground detonations with no documented history of release of particulate radionuclides or documented releases were very low (7 of 15 sites)

- Atmospheric or underground tests and detonations with possible release to surface soils (5 of 15 sites, including CAS 02-23-03, CAS 03-23-27, and CAS 03-23-29, which involved pulling a contaminated cable from a test hole; CAS 04-23-02, an atmospheric test; and CAS 18-23-02, a cratering test) 


\subsubsection{Time Constraints}

The study data will be evaluated considering the length of time that will be required to complete the closure process and the closure report, as allowed for by the SAFER process. Time constraints that may affect the schedule of this project include approval of the SAFER Plan and DQOs. In addition, if classified information must be accessed, additional time may be needed to complete the study.

\subsubsection{DeVelop the Analytic ApProach (STEP 5)}

Step 5 of the DQO process develops a decision rule statement ("If..., then...") that defines the conditions under which possible alternative actions will be chosen. In this step, the action levels are specified and the sensitivity of the historical analytical methods is evaluated.

\subsubsection{Decision Rules}

The decision rules are as follows:

- If it is determined, through evaluation of the information inputs, that there has not been a distinct, measurable release to the surface soils resulting from the associated historical operations, then no further action will be required.

- If it is determined that a distinct, measurable release to the surface soils resulted from the associated historical operations, then soil contamination levels will be determined and compared to action levels. This will be accomplished by evaluating the following:

- RIDP data, both in situ and soil sample values

- Aerial survey data where correlated

- Soil sampling data from like sites

- Soil sampling data collected in the vicinity of the site supporting other investigations

- If radiological concentrations in the soil are less than the action levels, then no further action will be required.

- If radiological concentrations are greater than action levels, then the risks to personnel and the environment will be evaluated to determine a path forward.

- If it is determined that clean closure is not feasible, the site(s) will be closed in place with administrative controls.

The decision flowchart is summarized in Figure 19.

\subsubsection{2 $\quad$ Action Levels}

The action levels for radiological contaminants are based on the National Council on Radiation Protection (NCRP)-recommended screening limits for construction, commercial, industrial land-use scenarios (NCRP, 1999) scaled to $25 \mathrm{mrem} / \mathrm{yr}$ dose constraint (Murphy, 2004) and 10 CFR 835, which provides guidelines for levels of radiological control depending on the levels of radiological hazards present (CFR, 1993). Remaining radiological contamination will be posted per the NV/YMP RadCon Manual (NNSA/NSO, 2004b). The action levels will be the greater of either the levels described above or the local area background levels. 


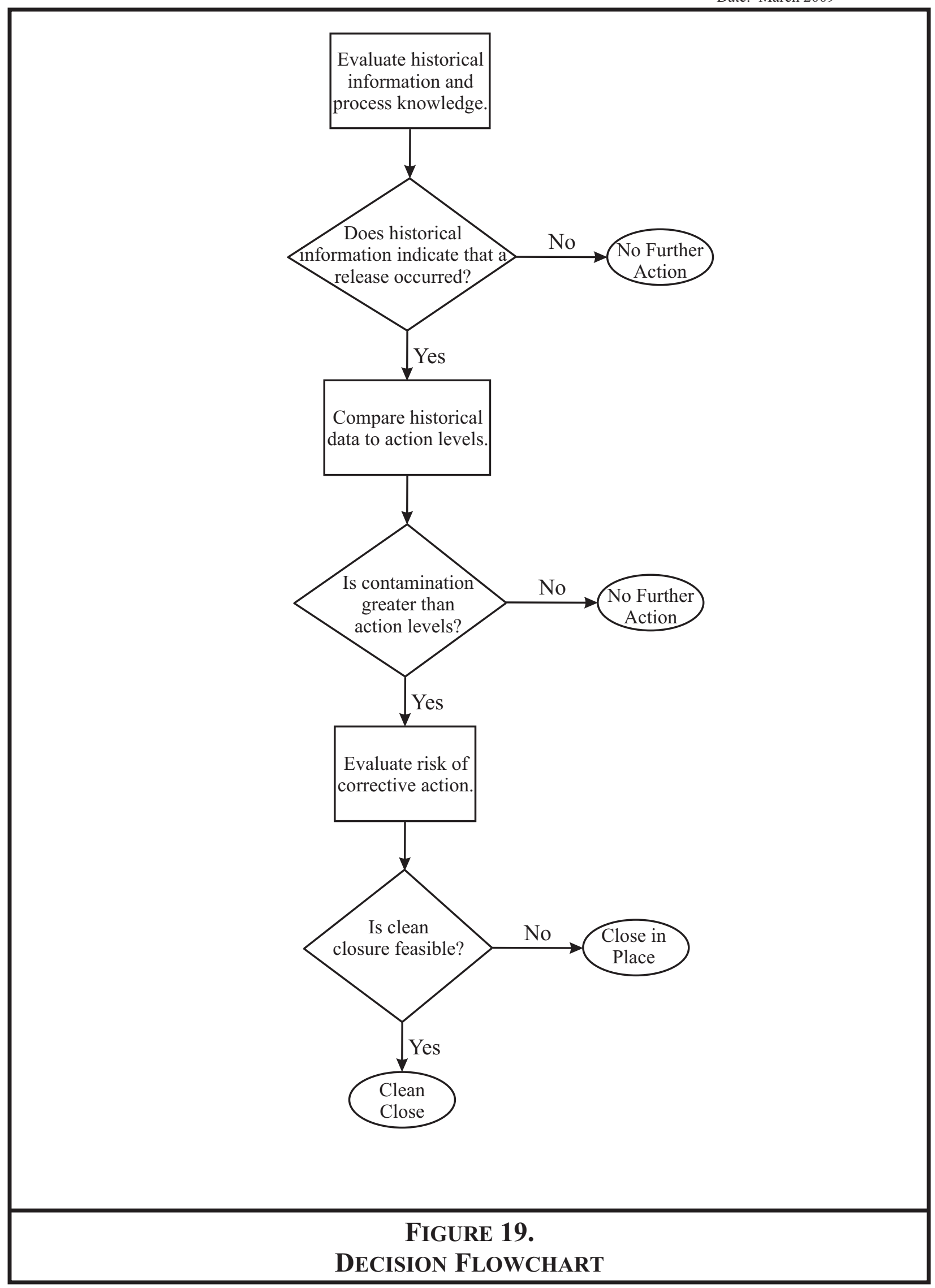




\subsubsection{Measurement and Analysis Sensitivity}

The historical measurement and analysis methods must be capable of measuring analyte concentrations at or below the corresponding action levels.

RIDP and aerial survey data allow calculations of minimum detectable activity. As appropriate, detection limits will be determined and compared to the action levels described above. Should detection limits be higher than the action levels, the detection limit will be used to make the appropriate closure decision, likely closure in place with administrative controls.

\subsubsection{Specify Performance Or ACCePtance Criteria (STep 6)}

Step 6 of the DQO process specifies performance criteria for the decision rules. Setting tolerable limits on decision errors requires the planning team to weigh the relative effects of threats to human health and the environment, expenditure of resources, and the consequences of an incorrect decision. This section provides an assessment of the possible outcomes of DQO decisions and the impact of those outcomes if the decisions are in error.

In general, confidence in DQO decisions will be established qualitatively by the following:

○ Developing CSMs

- Testing the validity of the CSMs based on an analysis of historical data

- Evaluating the quality of the data based on data quality indicator parameters

\subsubsection{Decision Errors}

The baseline condition (i.e., null hypothesis) is that soil has not been impacted with radionuclides at concentrations above action levels. The alternative condition is that the soil has been impacted with radionuclides at concentrations above action levels.

\section{False Rejection}

This error would mean deciding that the baseline condition is false when, in fact, it is true. This error means deciding that the soil is contaminated above action levels when it is not. The consequence of this decision is increased cost for the closure effort or post-closure requirements.

Several false positive errors have been identified through review of historical data. False positive errors include the determination that a release to the surface soils occurred as a result of a nuclear detonation when, in light of further historical investigation, it is demonstrated that such a release did not occur. Examples include CAS 01-23-02, where detonation occurred at 40,000 ft above ground, and CAS 03-23-24, where the only documented release involves very short-lived gaseous radionuclides.

\section{False Acceptance}

This error would mean deciding that the baseline condition is true when, in fact, it is false. This error means deciding that the soil is not contaminated when, in fact, it is contaminated above action levels. The potential consequence is an increased risk to human health and the environment. This error will be controlled by having a high degree of confidence that the data identify contamination, if present. To satisfy this criterion, the data will be closely evaluated to ensure that the data cover the areas of the sites and are adequate to detect contamination at or below the action levels. Further, since most of these sites are currently controlled for radiological purposes and there is no proximal public receptor, the impact of this error is minimized. 


\subsubsection{Develop the Plan for Obtaining Data (Step 7)}

Step 7 of the DQO process provides the general approach for resolving the decisions. The pool of existing data will be used to resolve the decisions outlined above.

\subsubsection{Process Knowledge}

The historical operations associated with these sites are well documented through multiple historical sources. Much of the operational information is based on semi-quantitative, or in some cases, quantitative data.

\subsubsection{Aerial Survey Data}

Detection limits for this data can be established. Aerial survey data provide 100-percent coverage of the study areas.

\subsubsection{Contaminated Lands Survey Data}

These data are semi-quantitative and have been found to be consistent with process knowledge, aerial survey data, and RIDP data where available.

\subsubsection{RIDP Data}

In general, RIDP did not cover these sites, as they were not suspected to contain surface contamination. In some cases, the RIDP study boundary for other soils sites extends into regions near the subject sites. If needed, RIDP data will be converted to units of picocuries per gram and compared to action levels. In general, evaluation of RIDP data will be used to support process knowledge assumptions and results of aerial surveys. RIDP survey areas were first determined through the use of aerial survey data. Aerial survey data provided a mechanism to bias study areas. Within each study area, survey and sampling points were determined through a statistical approach that generally provided higher measurement frequencies in areas of higher contamination and lower frequencies in areas of lower contamination.

Taken together, these data sets provide adequate information to do the following:

- Determine if there has been a distinct, measurable release to the surface soils resulting from the associated historical operations.

- Make comparisons to action levels as appropriate.

- Determine if appropriate controls are already in place, thus providing the basis for no further action.

- Identify cases in which appropriate controls are not in place, leading to closure in place with administrative controls. 


\subsection{RESUlts OF THE DQO ANALYSIS}

Results of the DQO analysis are presented in Section 2.0. The problem statement, "Conceptual corrective actions have been clearly identified based on historical data and background information. Are the sites sufficiently characterized to support closure through no further action and/or administrative controls?" has been resolved through the collection and evaluation of the items discussed in Section 3.1.3.1, Information Needs. The sites are sufficiently characterized to support the closure decisions described in this SAFER Plan. The evaluation found that there was sufficient process knowledge and historical characterization data to resolve the first goal of the study outlined in Section 3.1.2, Identify the Goal of the Study (Step 2). The resolution to the question, "Does historical information indicate that a release to ground surface soils occurred as a result of the associated test?" is presented in Section 2.0. Available historical documentation and characterization data indicate that a release to surface soils did not occur as a result of the associated tests. The decision rule outlined in Section 3.1.5.1, Decision Rules, states, "If it is determined, through evaluation of the information inputs, that there has not been a distinct, measurable release to the surface soils resulting from the associated historical operations, then no further action will be required." The sites will be closed as outlined in the SAFER Plan through the existing 10 CFR 835 controls. Table 48 provides a summary of the results of the evaluation for the CASs discussed in Section 2.0.

\subsubsection{ACTION LEVEL DETERMINATION AND BASIS}

Based on the evaluation presented in Section 2.0, releases of radionuclides to the surface soils as a result of the tests did not occur. The decision flowchart (Figure 19) indicates that the development of action levels is not required if a release to the surface soils did not occur.

\subsubsection{HYPOTHESIS TEST}

The null hypothesis is that a distinct, measurable release of radionuclides to the soils has not occurred as a result of the associated tests. The two types of decision errors are false rejection and false acceptance. A false rejection decision error would occur if it is determined that the soil is contaminated above action levels when it is not. The consequence of this decision is increased cost for the closure effort or post-closure requirements. A false acceptance decision error would occur if it is determined that the soil is not contaminated when, in fact, it is contaminated above action levels. The potential consequence is an increased risk to human health and the environment.

\subsubsection{Statistical Model}

A statistical model does not apply to closure of CAU 107.

\subsubsection{DESIGN DESCRIPTION/OPTION}

Because historical data have been used to determine a closure path for the sites in CAU 107 and additional data will not be collected, a design option for sampling is not applicable. 

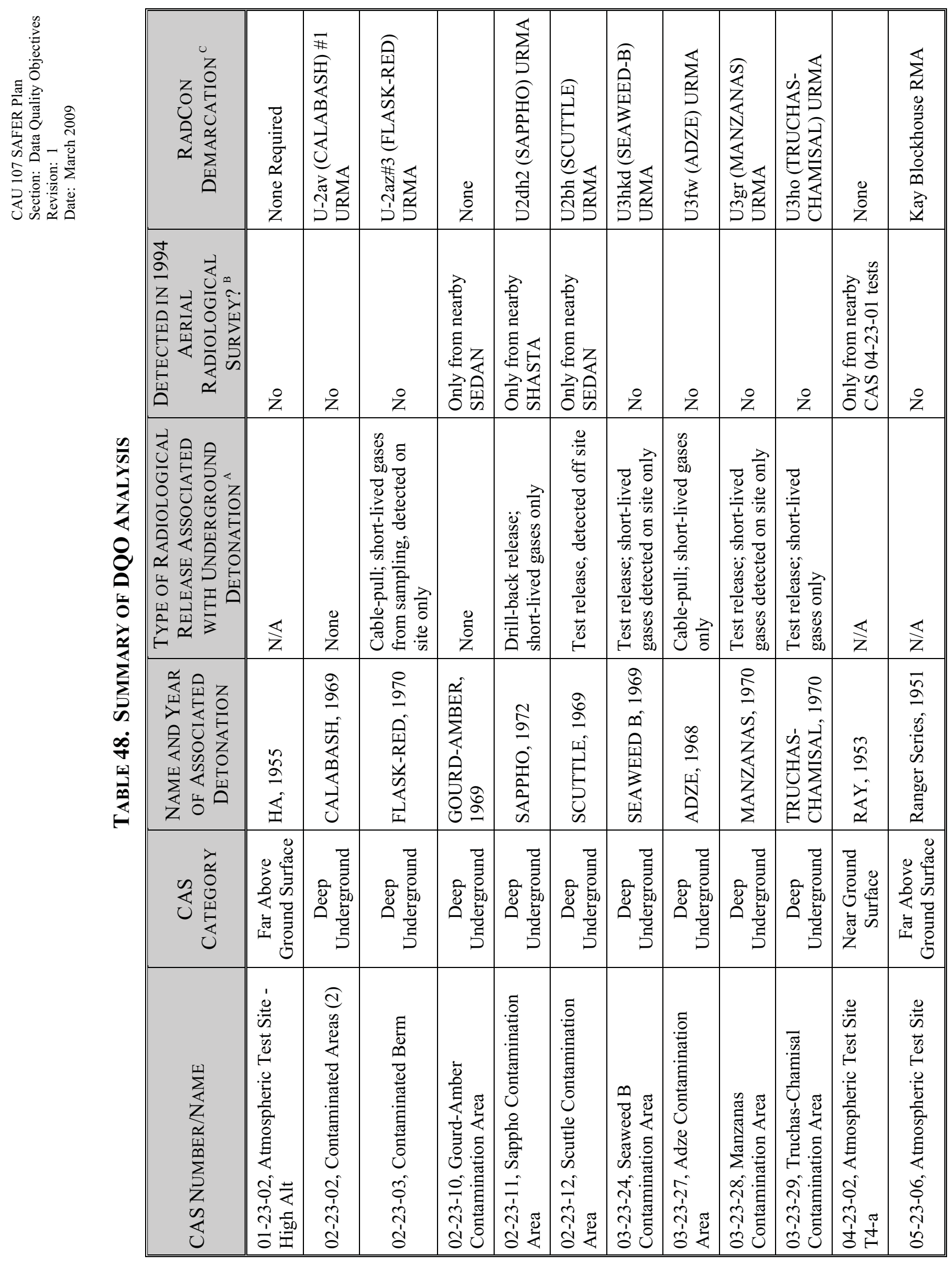


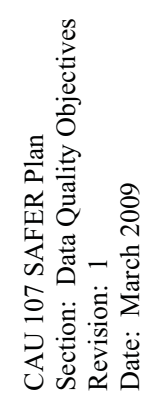

\begin{tabular}{|c|c|c|c|}
\hline 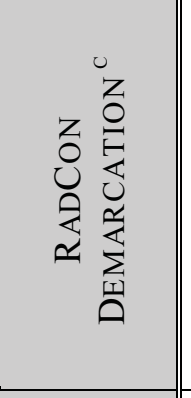 & 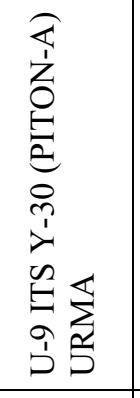 & $\begin{array}{l}0 \\
z \\
z\end{array}$ & 3 \\
\hline 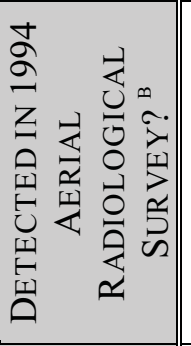 & 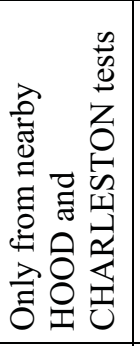 & 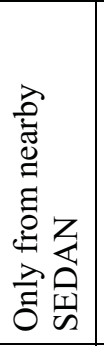 & \\
\hline 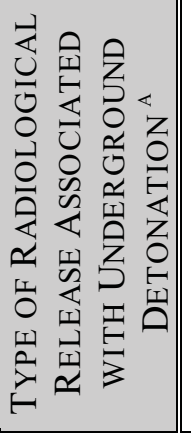 & 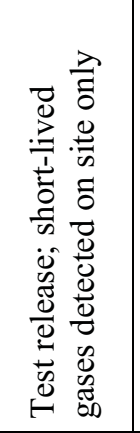 & $\overleftrightarrow{z}$ & $\frac{d}{\square}$ \\
\hline 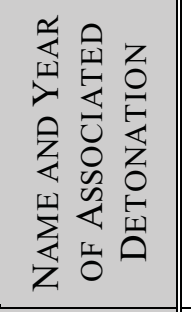 & \begin{tabular}{l}
0 \\
$\vdots$ \\
$\vdots$ \\
\multirow{1}{1}{} \\
$\vdots$ \\
0 \\
$\vdots$ \\
$\vdots$
\end{tabular} & $\begin{array}{l}\tilde{n} \\
\text { a } \\
z \\
\underline{1} \\
0\end{array}$ & 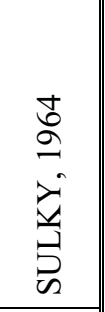 \\
\hline 齐 & 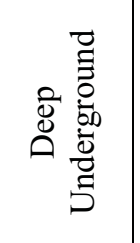 & 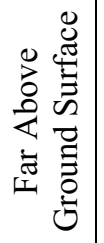 & ڤัँ \\
\hline 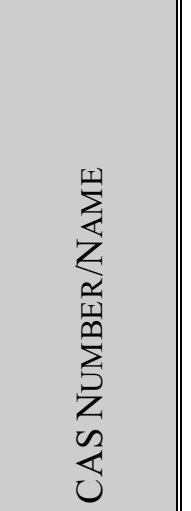 & 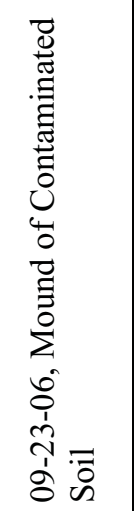 & 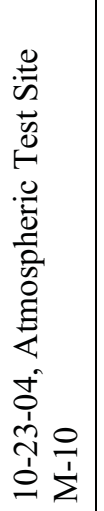 & c) \\
\hline
\end{tabular}

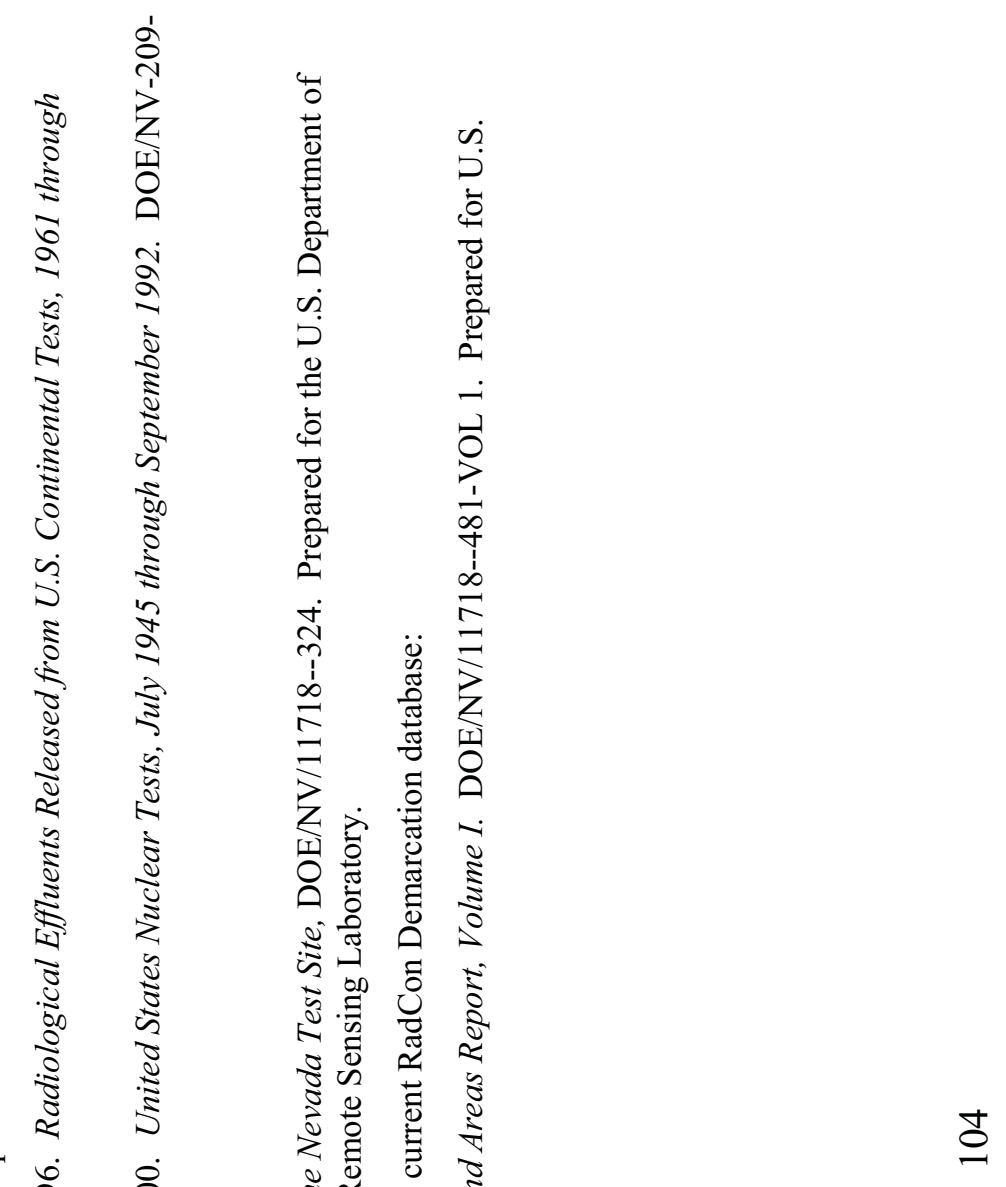




\subsubsection{Conceptual Site Model}

Through the review of the process knowledge and historical data presented in Section 2.0, the CSM for 13 of the $15 \mathrm{CASs}$ is that a distinct, measurable release of radionuclides to the soils has not occurred as a result of the associated tests. Data are adequate to support a closure option of no further action for these sites.

Historical evidence indicates that there is limited contamination within the potential crater area of the TRUCHAS-CHAMISAL detonation associated with CAS 03-23-29. However, levels are too low to be seen in fly-over data and do not pose a risk to workers or the environment. Data are adequate to support a closure option of closure in place with administrative controls. The site is in a stable condition and requires no additional controls; therefore, no additional closure activities will be conducted. The site is currently posted in compliance with 10 CFR 835 as a URMA. The Demarcation Project will monitor the area for continued compliance with 10 CFR 835.

Historical evidence also indicates that there may be limited contamination present at the SULKY site associated with CAS 18-23-02. However, levels are too low to be seen in fly-over data and do not pose a risk to workers or the environment. Data are adequate to support a closure option of closure in place with administrative controls. The site is in a stable condition and requires no additional controls; therefore, no additional closure activities will be conducted. The site is currently posted in compliance with 10 CFR 835 as an RMA. The Demarcation Project will monitor the area for continued compliance with 10 CFR 835. 
CAU 107 SAFER Plan

Section: Data Quality Objectives

Revision: 1

Date: March 2009

\section{THIS PAGE INTENTIONALLY LEFT BLANK}


CAU 107 Closure Report

Section: Appendix B

Revision: 0

Date: June 2009

\section{APPENDIX B}

\section{USE RESTRICTION DOCUMENTATION}


CAU 107 Closure Report

Section: Appendix B

Revision: 0

Date: June 2009

THIS PAGE INTENTIONALLY LEFT BLANK 


\section{CAU Use Restriction Information}

CAU Number/Description: CAU 107, Low Impact Soil Sites

Applicable CAS Numbers/Descriptions: CAS 03-23-29, Truchas-Chamisal Contamination Area

Contact (organization/project): NNSA/NSO Federal Soils Sub-Project Director

Surveyed Area (UTM, Zone 11, NAD 27, meters):

\begin{tabular}{|c|c|c|}
\hline UR POINTS & NORTHING & EASTING \\
\hline \hline 1 & $4,096,690.782$ & $587,411.264$ \\
\hline 2 & $4,096,684.843$ & $587,409.061$ \\
\hline 3 & $4,096,676.423$ & $587,408.645$ \\
\hline 4 & $4,096,668.348$ & $587,409.332$ \\
\hline 5 & $4,096,660.959$ & $587,412.595$ \\
\hline 6 & $4,096,655.711$ & $587,420.255$ \\
\hline 7 & $4,096,654.922$ & $587,428.399$ \\
\hline 8 & $4,096,659.179$ & $587,436.009$ \\
\hline 9 & $4,096,666.261$ & $587,440.578$ \\
\hline 10 & $4,096,672.387$ & $587,443.425$ \\
\hline 11 & $4,096,678.803$ & $587,445.058$ \\
\hline 12 & $4,096,686.153$ & $587,442.065$ \\
\hline 13 & $4,096,691.487$ & $587,436.917$ \\
\hline 14 & $4,096,695.806$ & $587,429.858$ \\
\hline 15 & $4,096,696.674$ & $587,426.975$ \\
\hline 16 & $4,096,697.828$ & $587,422.939$ \\
\hline 17 & $4,096,696.195$ & $587,416.784$ \\
\hline
\end{tabular}

Survey Date: $\underline{04 / 22 / 2009}$ Survey Method (GPS, etc): $\underline{\text { GPS }}$

Site Monitoring Requirements: Visual Inspections

Required Frequency (quarterly, annually?): Annual

If Monitoring Has Started, Indicate last Completion Date: N/A

\section{Use Restrictions}

The future use of any land related to this Corrective Action Unit (CAU), as described by the above surveyed location, is restricted from any DOE or Air Force activity that may alter or modify the containment control as approved by the state and identified in the CAU Closure Report or other CAU documentation unless appropriate concurrence is obtained in advance. 
Comments: A use restriction (UR) has been implemented for assumed radioactive contamination that could cause a dose greater than 25 millirems per year. The future use of the UR area is restricted from any activity that may alter or modify the containment controls, unless appropriate concurrence is obtained in advance. Annual site inspections are required to ensure that the signs are intact and legible and that the UR is maintained. Maintenance or repair needs that are identified will be completed prior to the following inspection. Inspection results will be documented in the annual combined Nevada Test Site post-closure letter report.

Submitted By: $\quad$ /S/K Cabble

Date: $6-2 z-09$

cc with copy of survey map (paper and digital (dgn) formats): CAU Files ( 2 copies) 


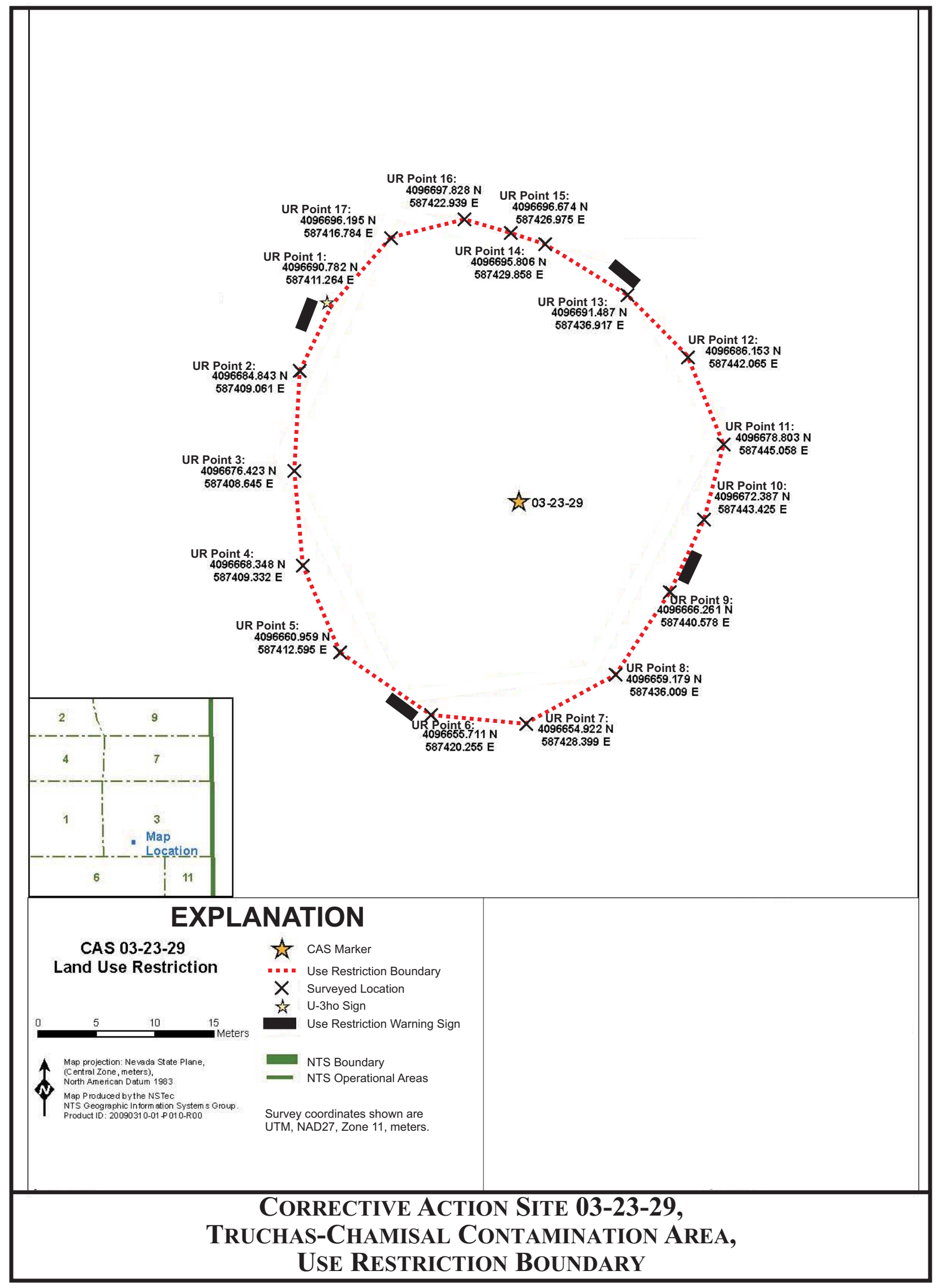




\section{CAU Use Restriction Information}

CAU Number/Description: CAU 107, Low Impact Soil Sites

Applicable CAS Numbers/Descriptions: CAS 18-23-02, U-18d Crater (Sulky)

Contact (organization/project): NNSA/NSO Federal Soils Sub-Project Director

Surveyed Area (UTM, Zone 11, NAD 27, meters):

\begin{tabular}{|c|c|c|}
\hline UR POINTS & NORTHING & EASTING \\
\hline 1 & $4,104,023.018$ & $558,454.515$ \\
\hline 2 & $4,104,031.600$ & $558,462.026$ \\
\hline 3 & $4,104,038.755$ & $558,464.615$ \\
\hline 4 & $4,104,045.205$ & $558,465.805$ \\
\hline 5 & $4,104,054.236$ & $558,464.857$ \\
\hline 6 & $4,104,062.951$ & $558,461.336$ \\
\hline 7 & $4,104,068.665$ & $558,456.962$ \\
\hline 8 & $4,104,073.591$ & $558,450.627$ \\
\hline 9 & $4,104,077.290$ & $558,438.425$ \\
\hline 10 & $4,104,076.875$ & $558,429.150$ \\
\hline 11 & $4,104,073.763$ & $558,420.499$ \\
\hline 12 & $4,104,068.193$ & $558,413.237$ \\
\hline 13 & $4,104,065.966$ & $558,411.302$ \\
\hline 14 & $4,104,047.264$ & $558,404.375$ \\
\hline 15 & $4,104,041.512$ & $558,404.639$ \\
\hline 16 & $4,104,036.056$ & $558,405.921$ \\
\hline 17 & $4,104,027.441$ & $558,410.827$ \\
\hline 18 & $4,104,021.149$ & $558,417.753$ \\
\hline 19 & $4,104,017.822$ & $558,424.938$ \\
\hline 21 & $4,104,016.679$ & $558,429.358$ \\
\hline 22 & $4,104,016.046$ & $558,435.564$ \\
\hline 23 & $4,104,016.496$ & $558,441.352$ \\
\hline & $4,104,018.607$ & $558,447.337$ \\
\hline
\end{tabular}

Survey Date: $\underline{04 / 23 / 2009}$ Survey Method (GPS, etc): $\underline{\text { GPS }}$

Site Monitoring Requirements: Visual Inspections

Required Frequency (quarterly, annually?): Annual

If Monitoring Has Started, Indicate last Completion Date: N/A 


\section{Use Restrictions}

The future use of any land related to this Corrective Action Unit (CAU), as described by the above surveyed location, is restricted from any DOE or Air Force activity that may alter or modify the containment control as approved by the state and identified in the CAU Closure Report or other CAU documentation unless appropriate concurrence is obtained in advance.

Comments: A use restriction (UR) has been implemented for assumed radioactive contamination that could cause a dose greater than 25 millirems per year. The future use of the UR area is restricted from any activity that may alter or modify the containment controls, unless appropriate concurrence is obtained in advance. Annual site inspections are required to ensure that the signs are intact and legible and that the UR is maintained. Maintenance or repair needs that are identified will be completed prior to the following inspection. Inspection results will be documented in the annual combined Nevada Test Site post-closure letter report.

Submitted By: /S/K Cabble

Date:

$6-z z-09$

cc with copy of survey map (paper and digital (dgn) formats): CAU Files ( 2 copies) 


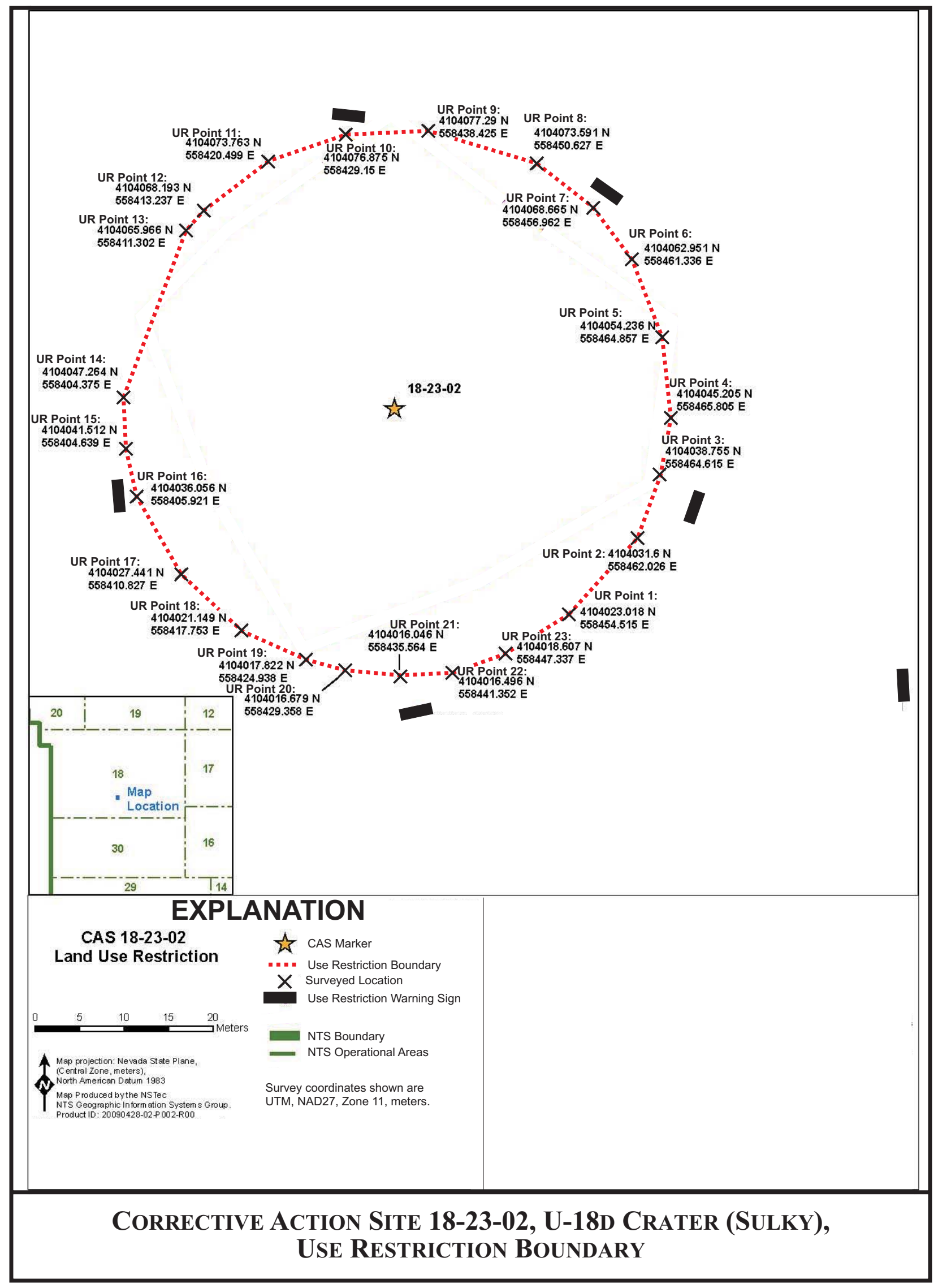


CAU 107 Closure Report

Section: Appendix C

Revision: 0

Date: June 2009

\section{APPENDIX C}

\section{SITE CLOSURE PHOTOGRAPHS}


CAU 107 Closure Report

Section: Appendix C

Revision: 0

Date: June 2009

THIS PAGE INTENTIONALLY LEFT BLANK 
PhOtOGRAPH Log

\begin{tabular}{|c|c|c||}
\hline $\begin{array}{c}\text { PhOTOGRAPH } \\
\text { NuMBER }\end{array}$ & \multicolumn{1}{|c||}{ DATE } & \multicolumn{1}{c||}{ CORRECTIVE ACTION SITE } \\
\hline \hline 1 & $02 / 17 / 2009$ & $01-23-02$, Atmospheric Test Site - High Alt \\
\hline 2 & $02 / 17 / 2009$ & $02-23-02$, Contaminated Areas (2) \\
\hline 3 & $02 / 17 / 2009$ & $02-23-03$, Contaminated Berm \\
\hline 4 & $02 / 17 / 2009$ & $02-23-10$, Gourd-Amber Contamination Area \\
\hline 5 & $02 / 17 / 2009$ & $02-23-11$, Sappho Contamination Area \\
\hline 6 & $02 / 17 / 2009$ & $02-23-12$, Scuttle Contamination Area \\
\hline 7 & $02 / 17 / 2009$ & $03-23-24$, Seaweed B Contamination Area \\
\hline 8 & $02 / 17 / 2009$ & $03-23-27$, Adze Contamination Area \\
\hline 9 & $12 / 11 / 2008$ & $03-23-28$, Manzanas Contamination Area \\
\hline 10 & $04 / 20 / 2009$ & $03-23-29$, Truchas-Chamisal Contamination Area \\
\hline 11 & $02 / 17 / 2009$ & $04-23-02$, Atmospheric Test Site T4-a \\
\hline 12 & $02 / 17 / 2009$ & $05-23-06$, Atmospheric Test Site \\
\hline 13 & $02 / 17 / 2009$ & $09-23-06$, Mound of Contaminated Soil \\
\hline 14 & $02 / 17 / 2009$ & $10-23-04$, Atmospheric Test Site M-10 \\
\hline 15 & $04 / 16 / 2009$ & $18-23-02$, U-18d Crater (Sulky) \\
\hline
\end{tabular}


CAU 107 Closure Report

Section: Appendix C

Revision: 0

Date: June 2009

\section{THIS PAGE INTENTIONALLY LEFT BLANK}




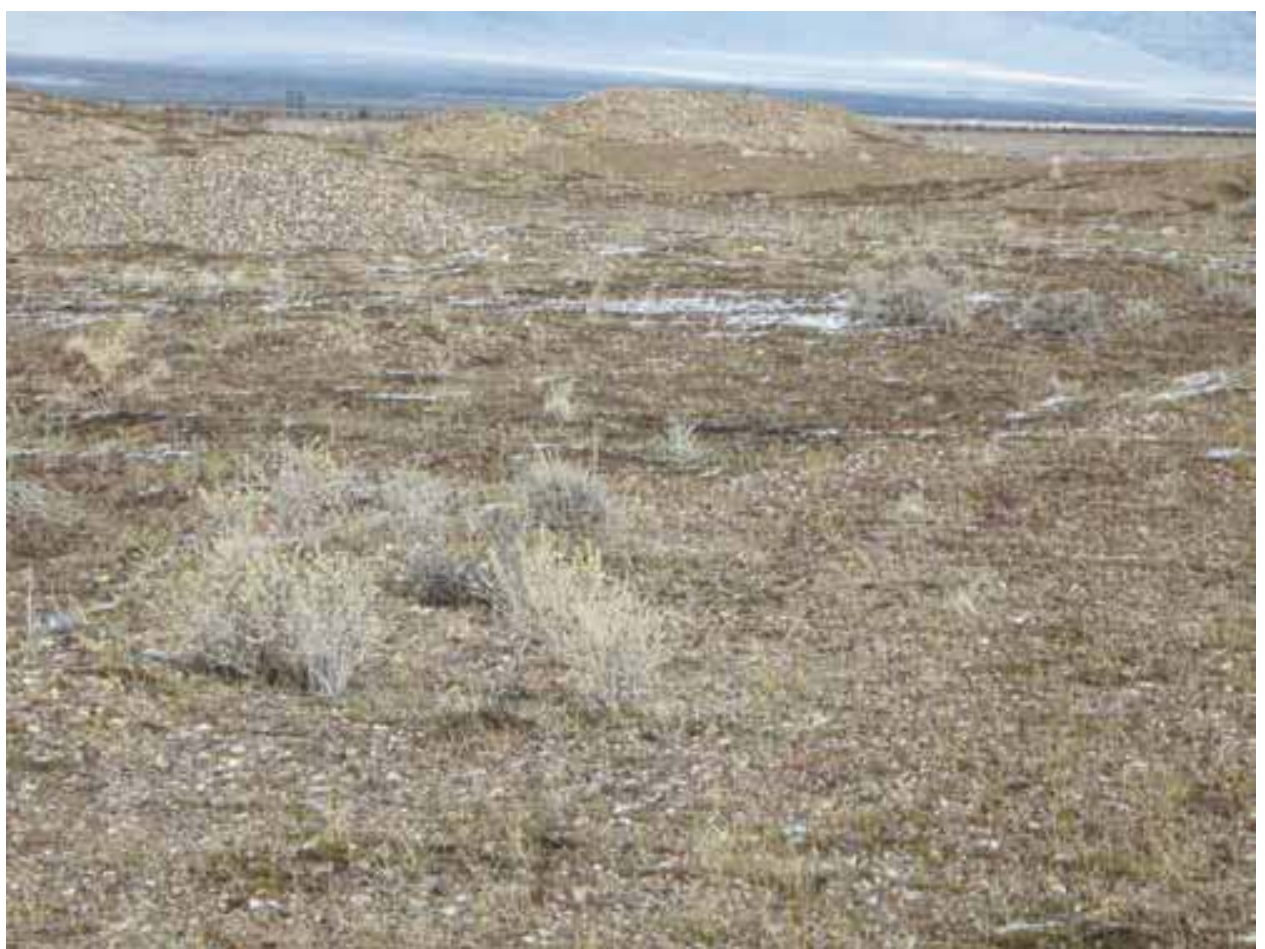

Photograph 1: CAS 01-23-02, Atmospheric Test Site - High Alt, 02/17/2009

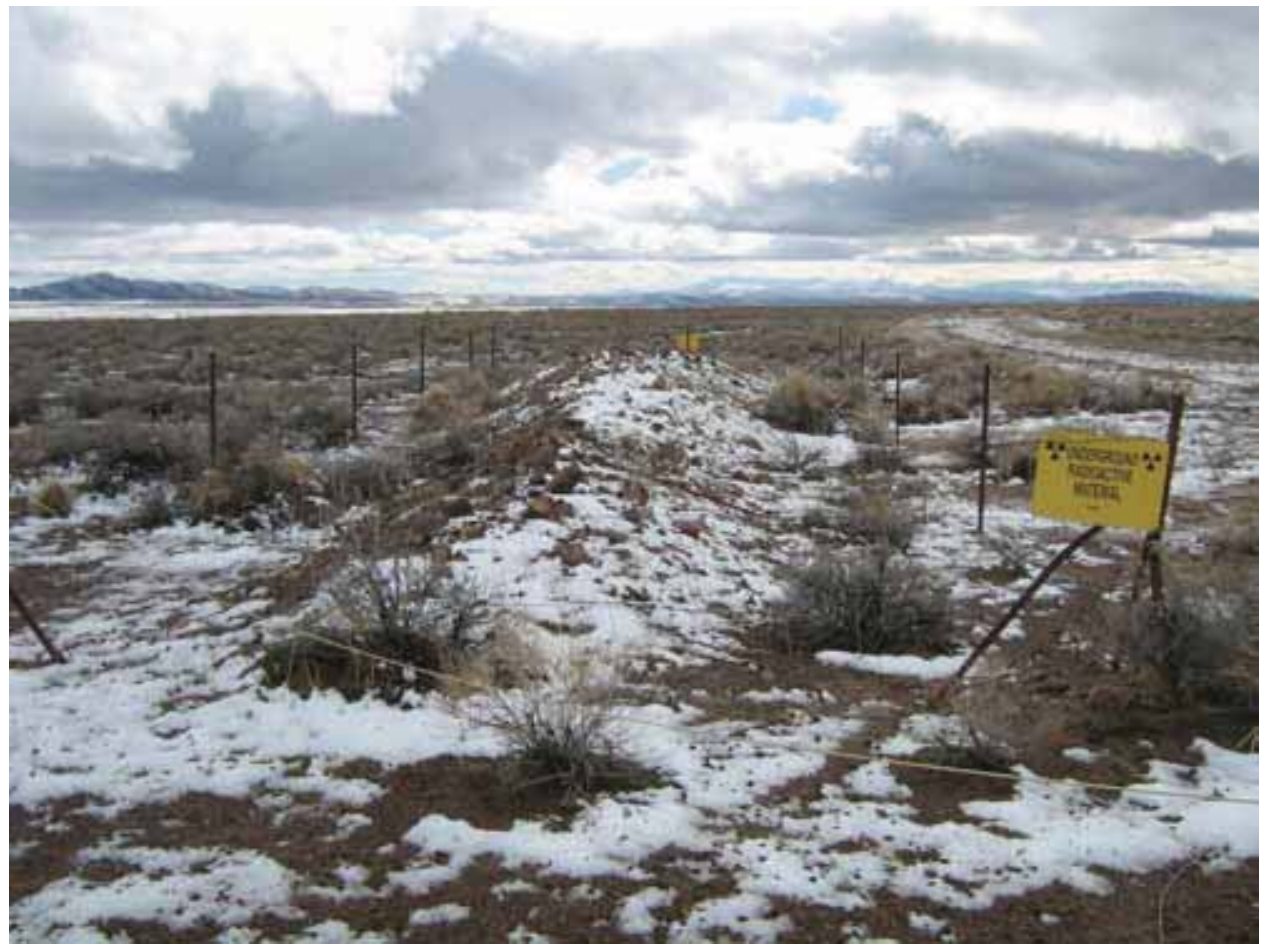

Photograph 2: CAS 02-23-02, Contaminated Areas (2), 02/17/2009 


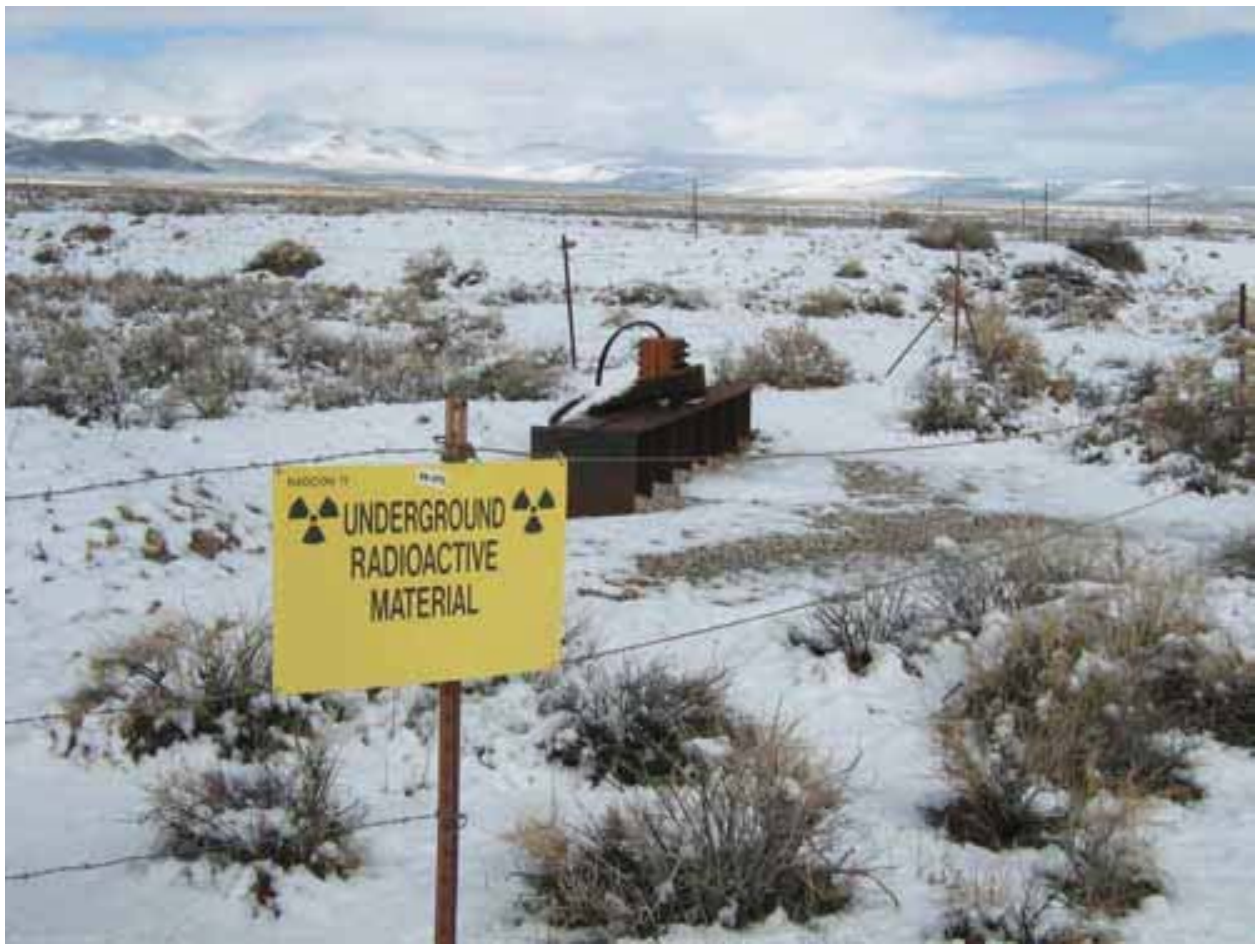

Photograph 3: CAS 02-23-03, Contaminated Berm, 02/17/2009

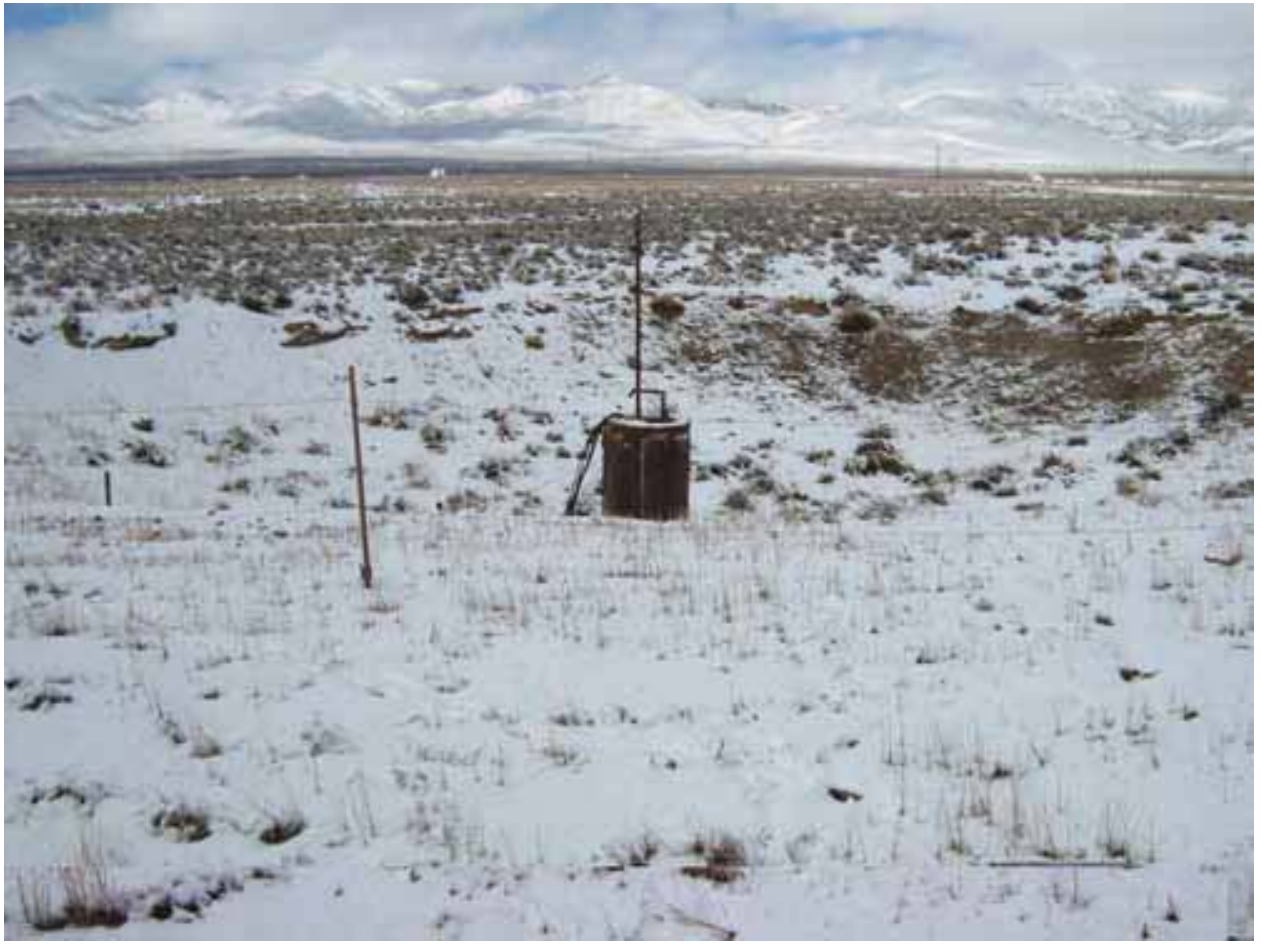

Photograph 4: CAS 02-23-10, Gourd-Amber Contamination Area, 02/17/2009 


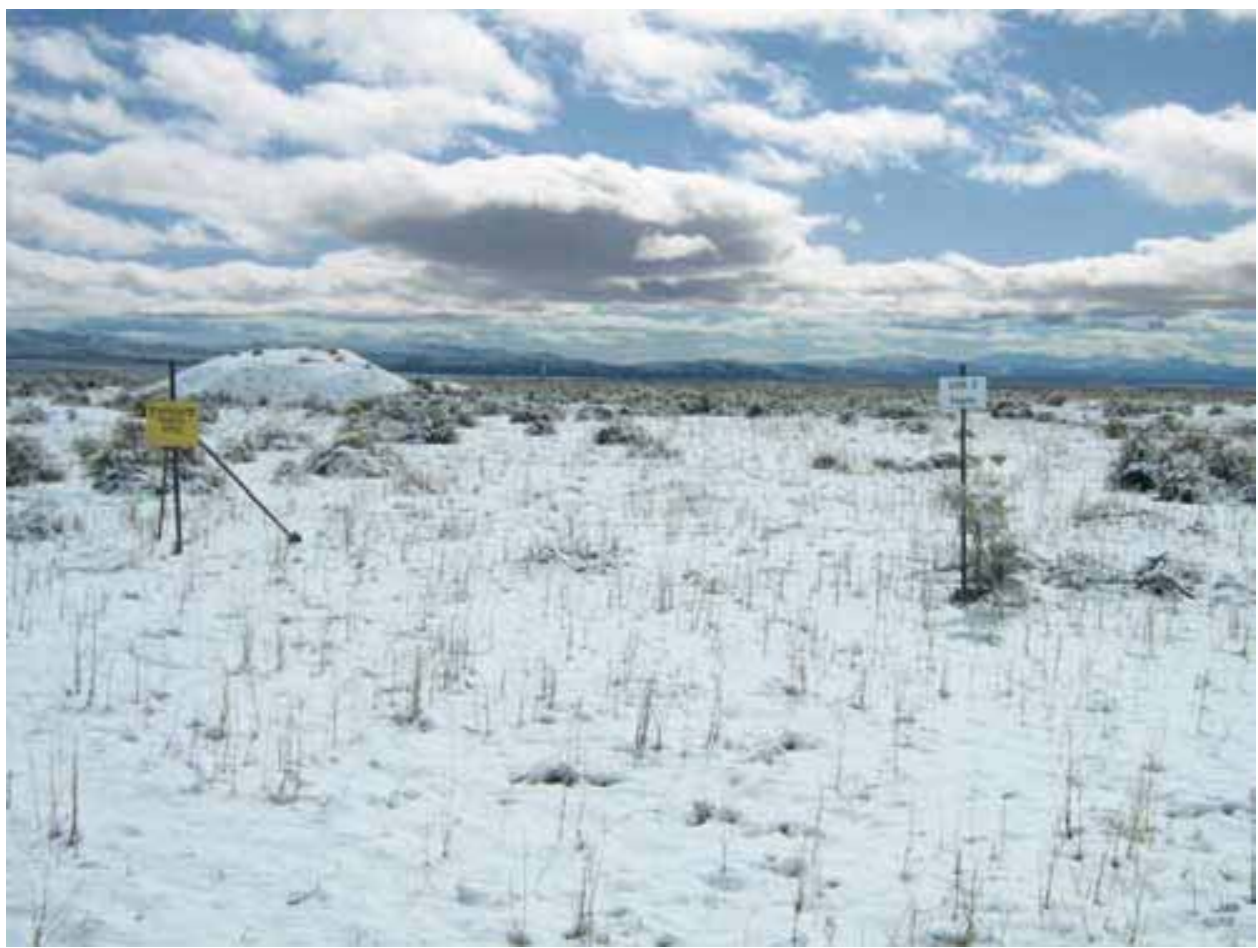

Photograph 5: CAS 02-23-11, Sappho Contamination Area, 02/17/2009

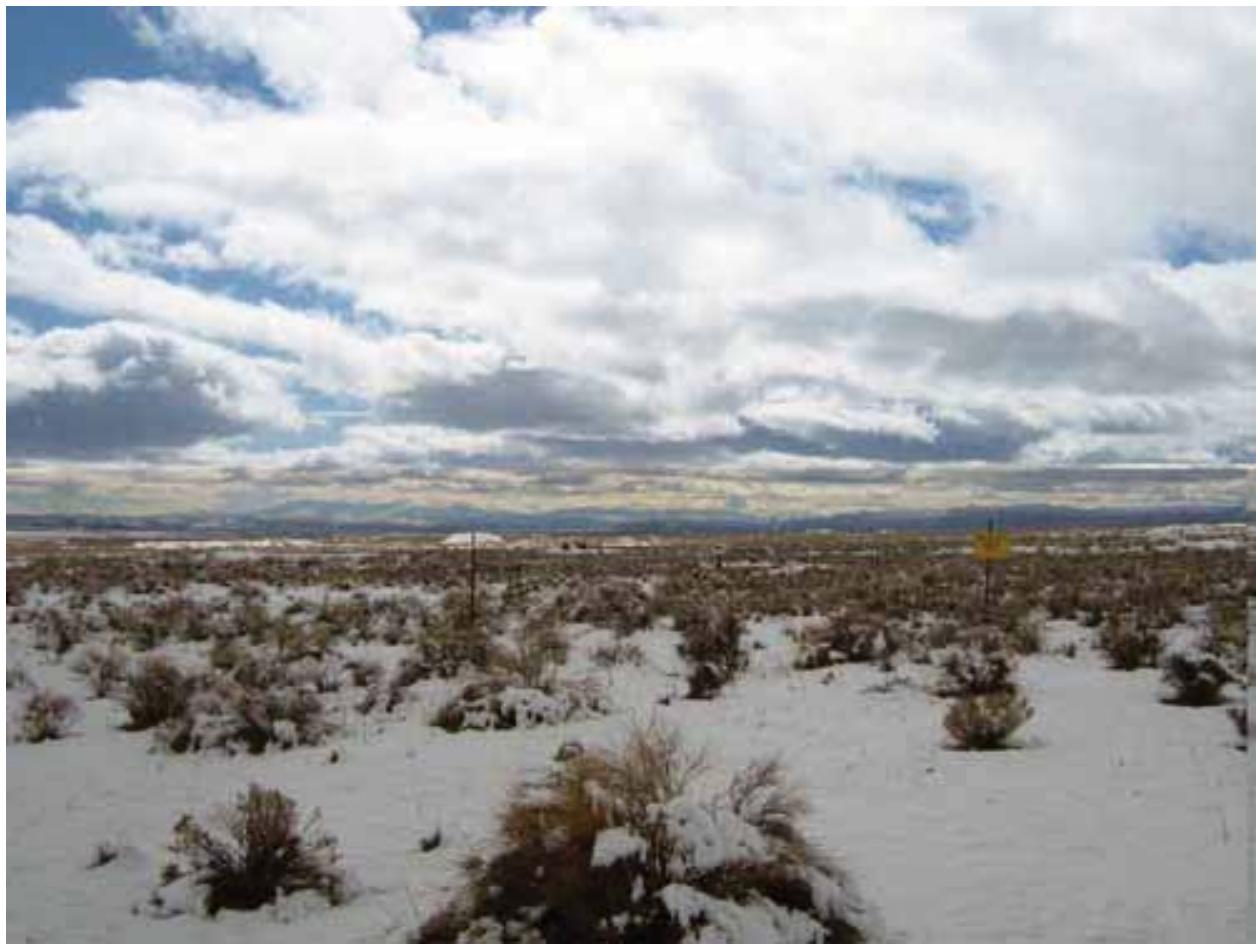

Photograph 6: CAS 02-23-12, Scuttle Contamination Area, 02/17/2009 


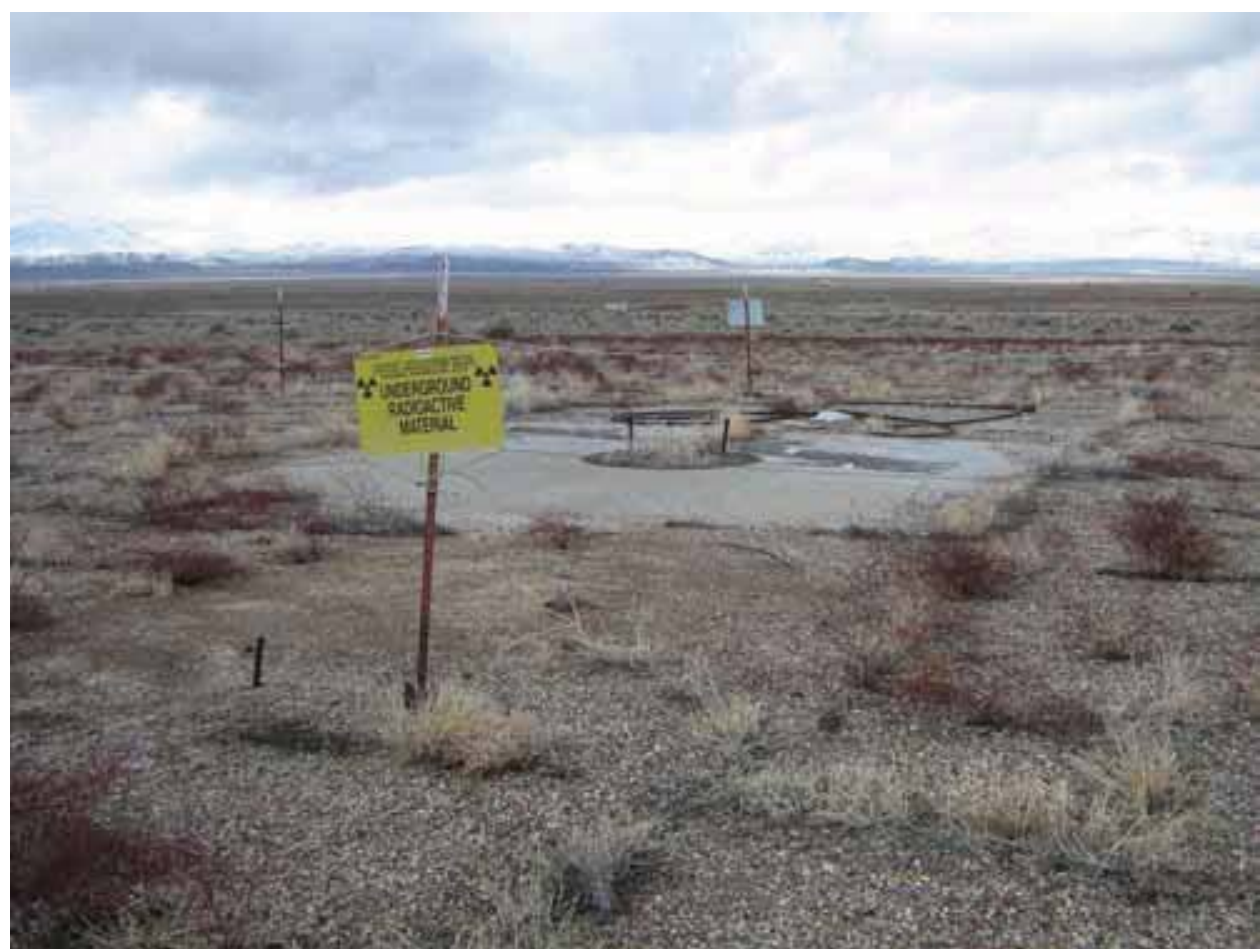

Photograph 7: CAS 03-23-24, Seaweed B Contamination Area, 02/17/2009
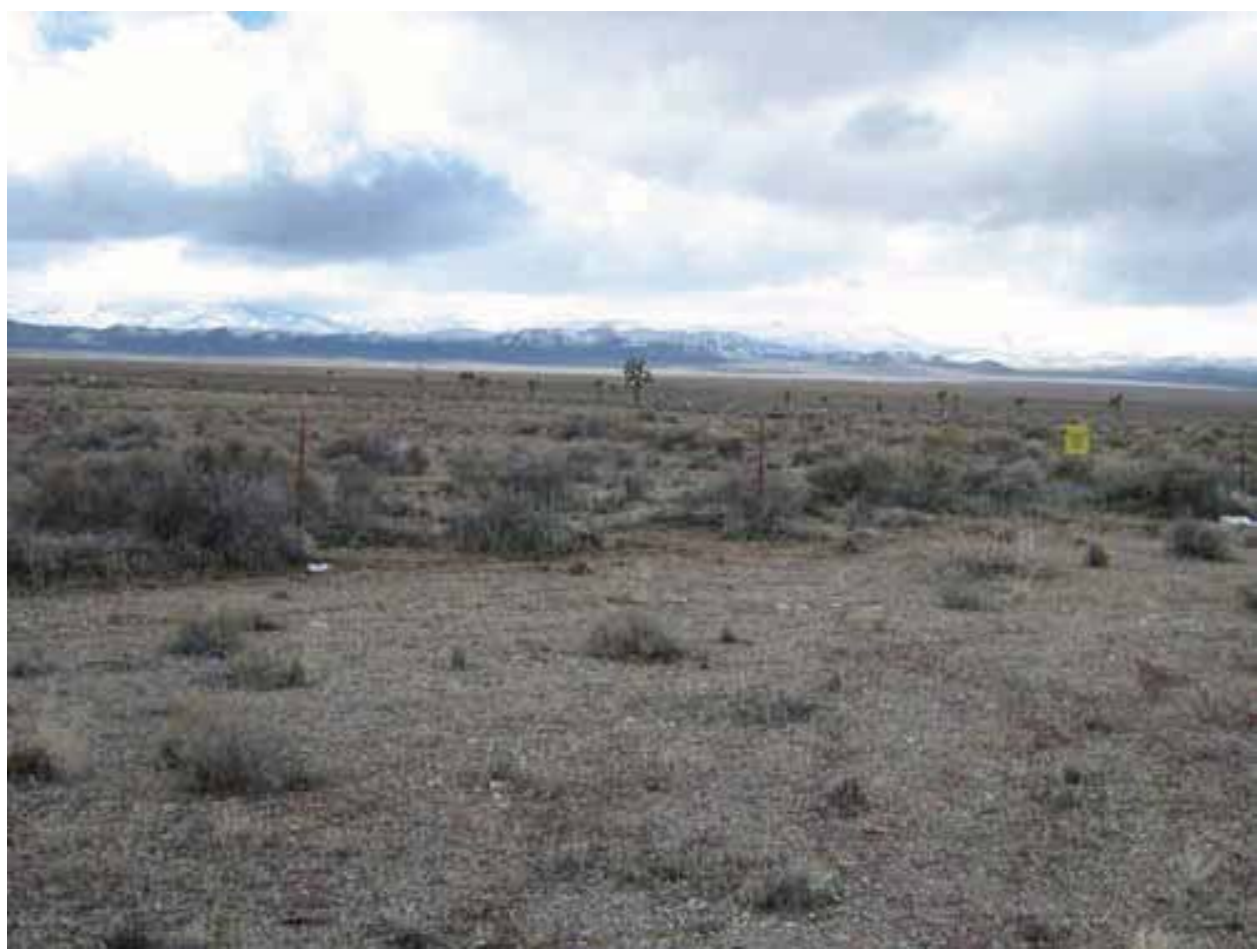

Photograph 8: CAS 03-23-27, Adze Contamination Area, 02/17/2009 


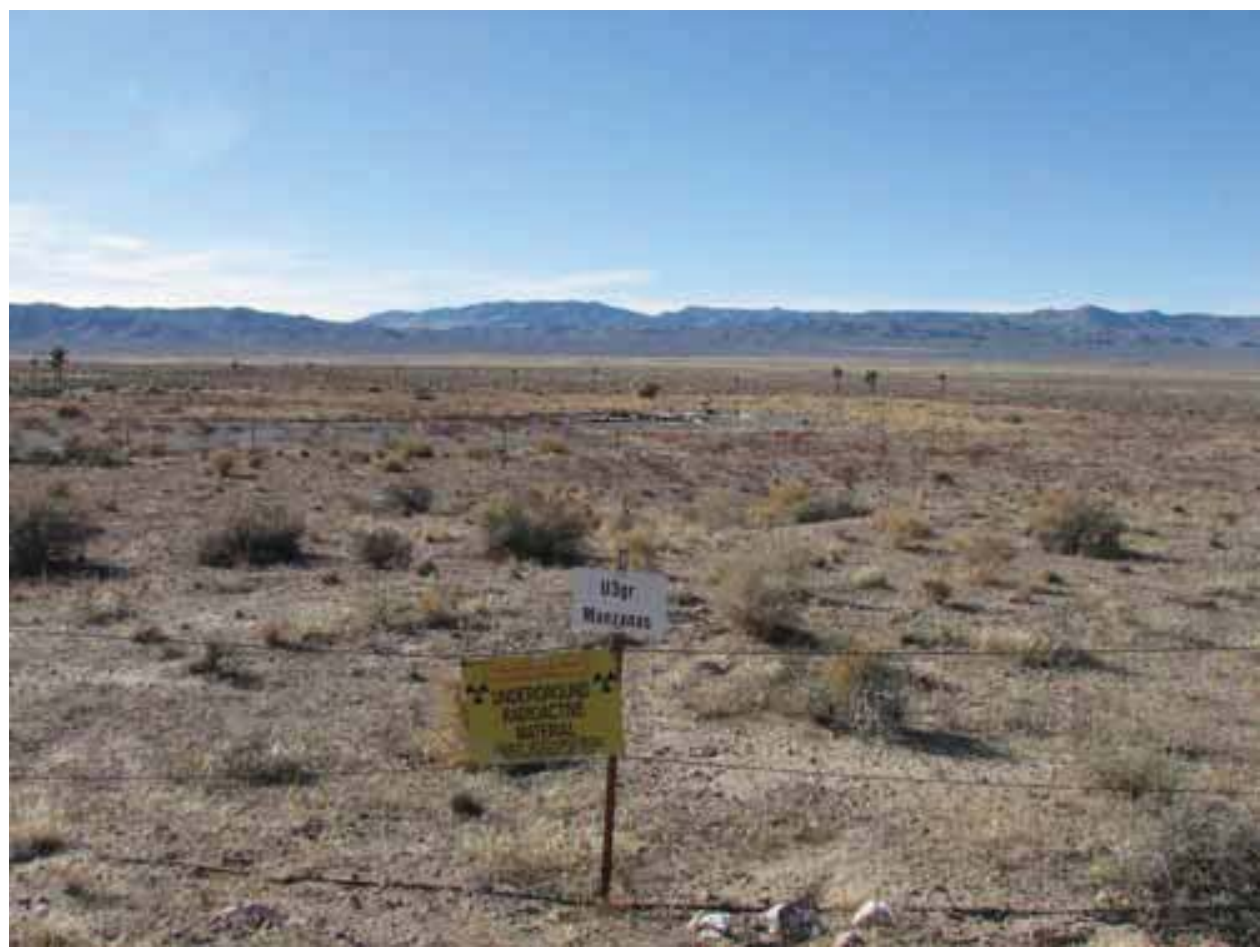

Photograph 9: CAS 03-23-28, Manzanas Contamination Area, 12/11/2008

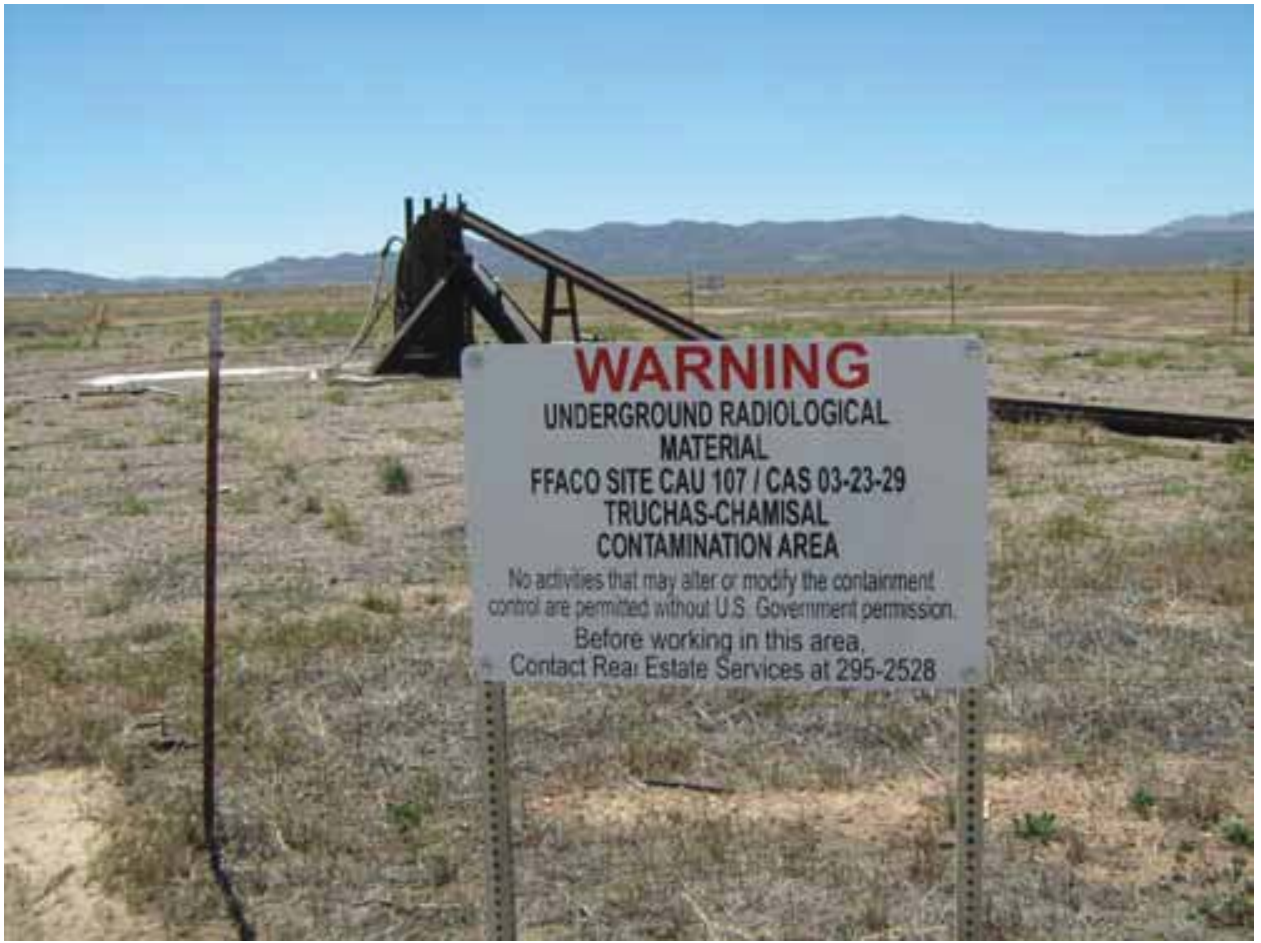

Photograph 10: CAS 03-23-29, Truchas-Chamisal Contamination Area, 04/20/2009 


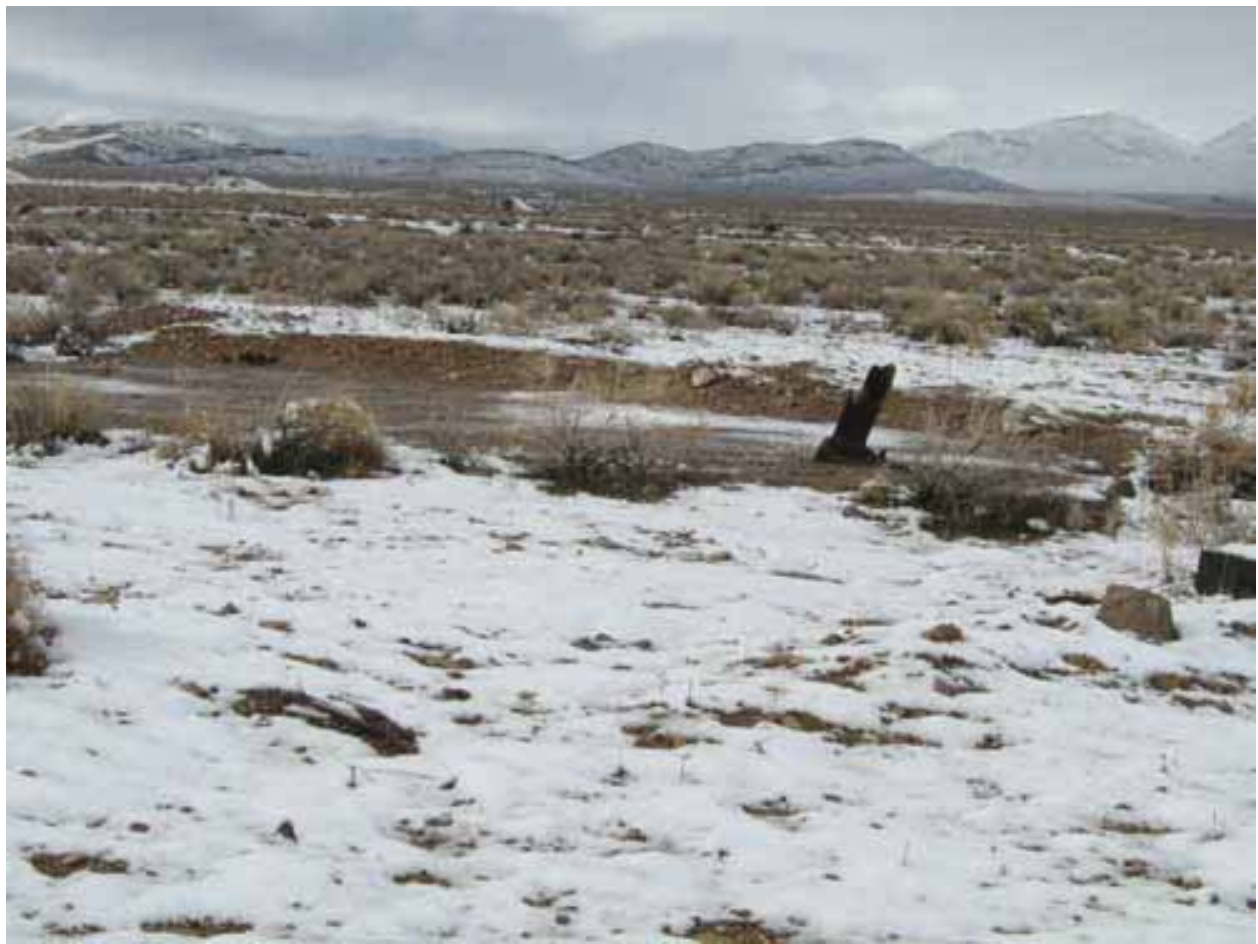

Photograph 11: CAS 04-23-02, Atmospheric Test Site T4-a, 02/17/2009

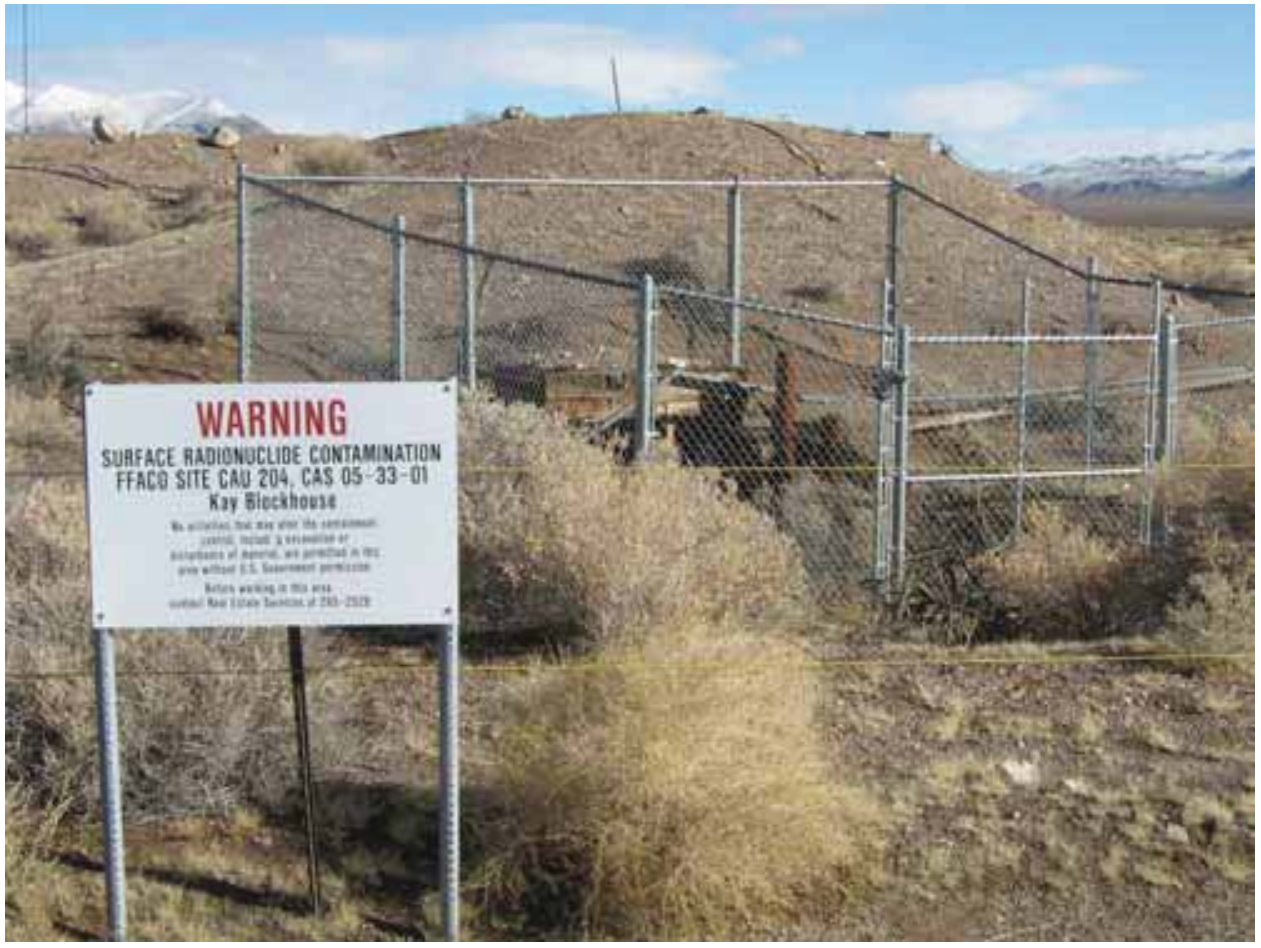

Photograph 12: CAS 05-23-06, Atmospheric Test Site, 02/17/2009 


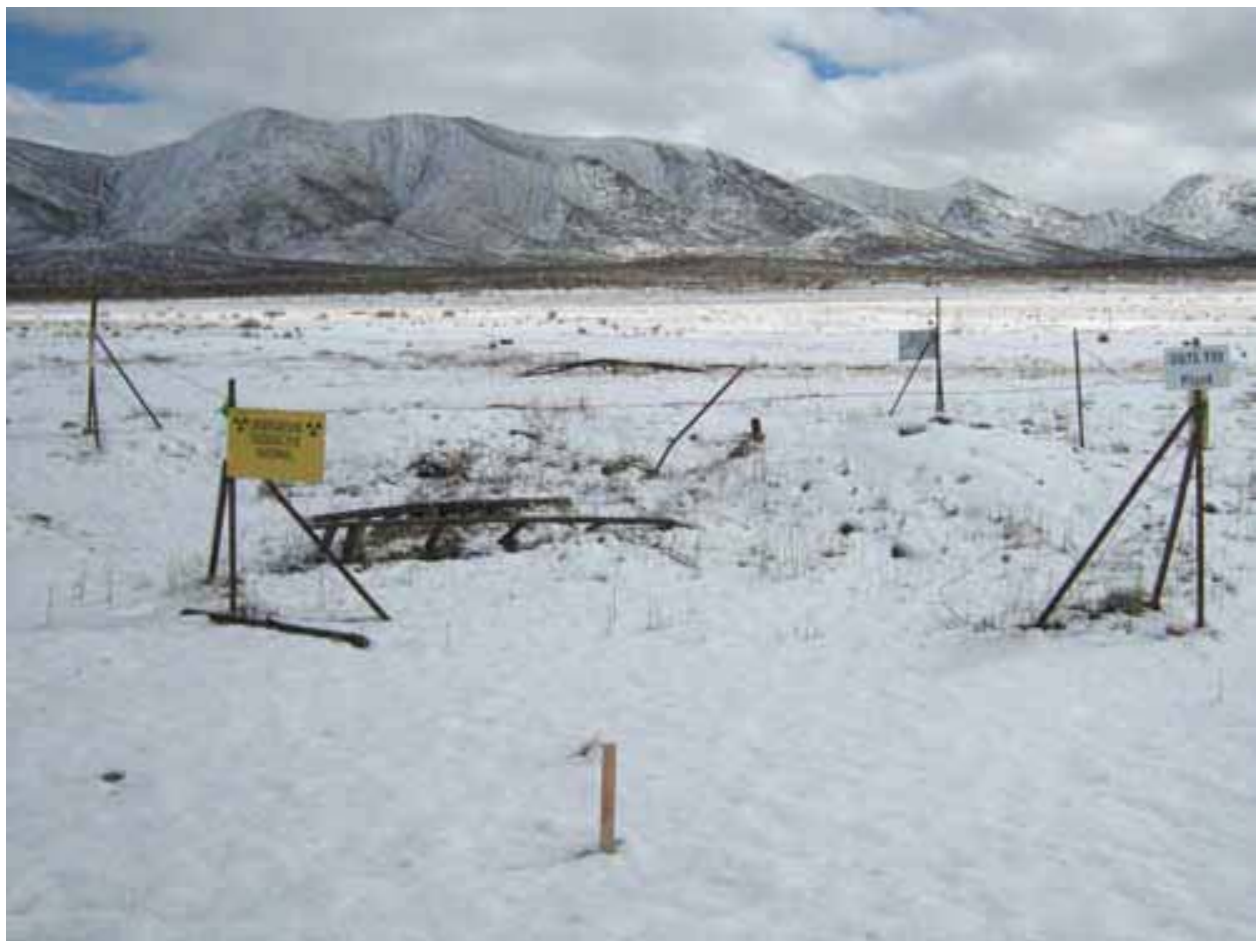

Photograph 13: CAS 09-23-06, Mound of Contaminated Soil, 02/17/2009

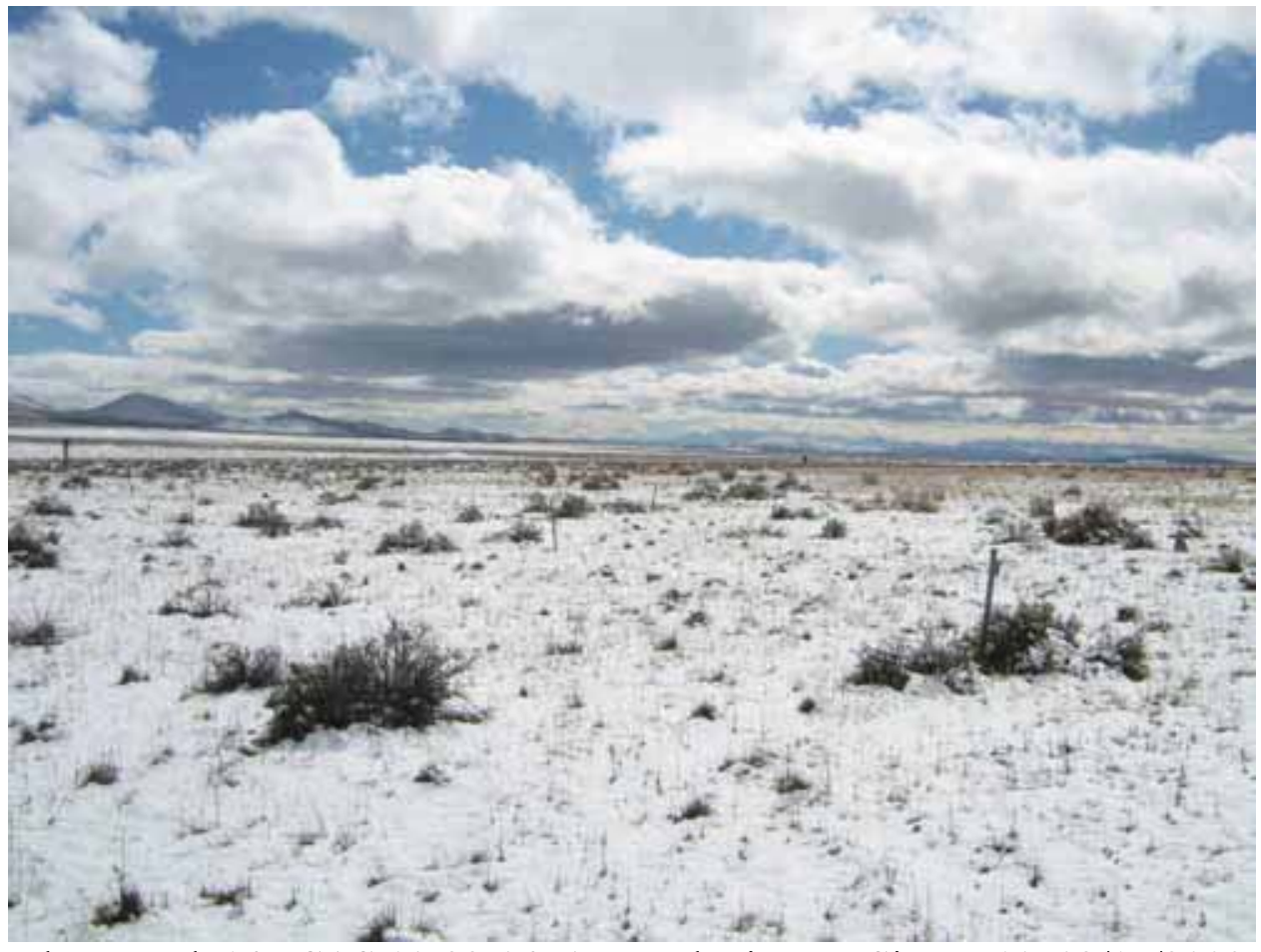

Photograph 14: CAS 10-23-04, Atmospheric Test Site M-10, 02/17/2009 


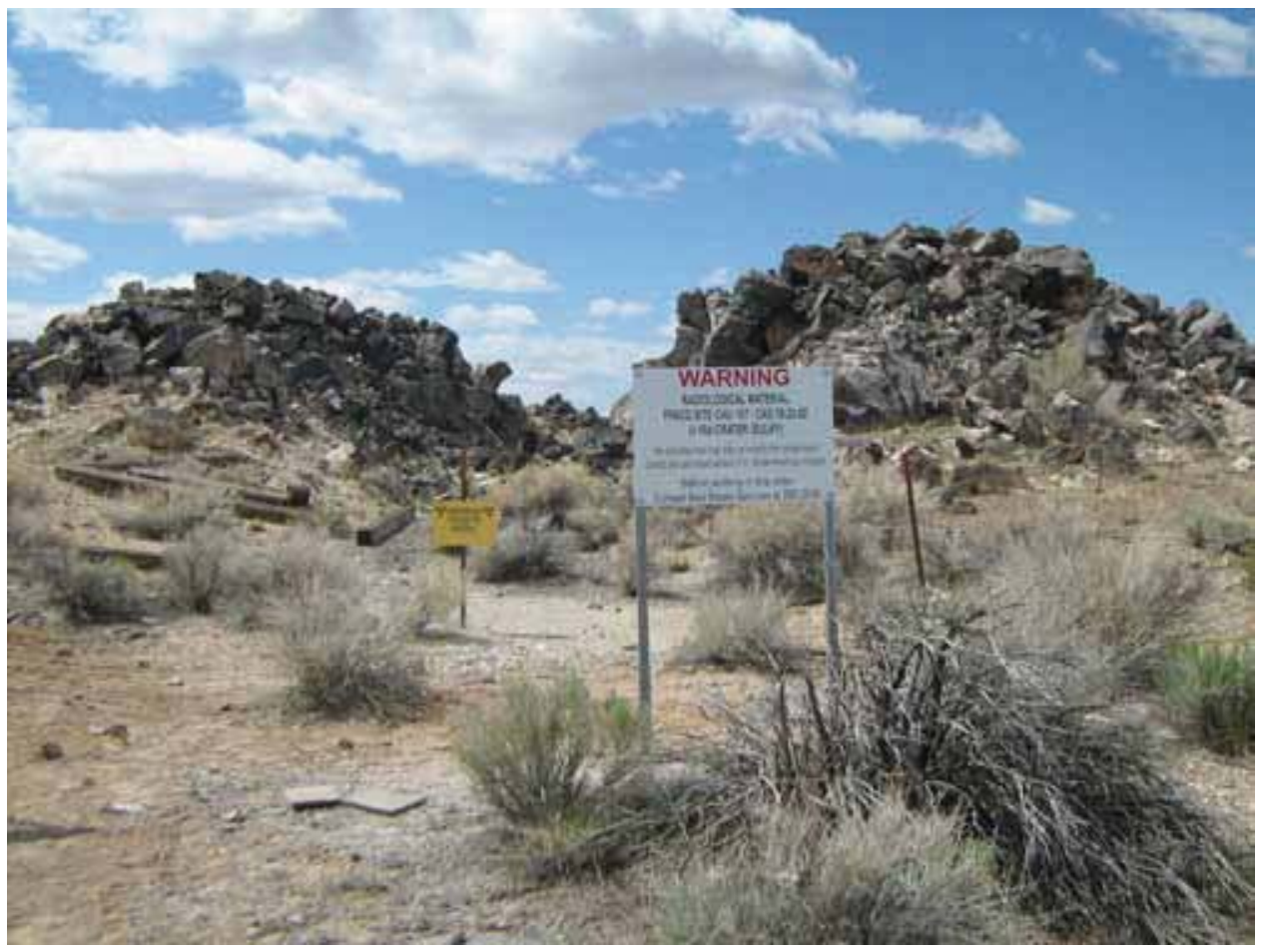

Photograph 15: CAS 18-23-02, U-18d Crater (Sulky), 04/16/2009 
CAU 107 Closure Report

Section: Library Distribution List

Revision: 0

Date: June 2009

\section{LIBRARY DISTRIBUTION LIST}


CAU 107 Closure Report

Section: Library Distribution List

Revision: 0

Date: June 2009

\section{THIS PAGE INTENTIONALLY LEFT BLANK}




\section{LIBRARY DISTRIBUTION LIST}

U.S. Department of Energy

National Nuclear Security Administration

Nevada Site Office

Technical Library

P.O. Box 98518, M/S 505

Las Vegas, NV 89193-8518

U.S. Department of Energy

Office of Scientific and Technical Information

P.O. Box 62

Oak Ridge, TN 37831-0062

Southern Nevada Public Reading Facility

c/o Nuclear Testing Archive

P.O. Box 98521, M/S 400

Las Vegas, NV 89193-8521

Manager, Northern Nevada FFACO

Public Reading Facility

c/o Nevada State Library \& Archives

Carson City, NV 89701-4285
1 (Uncontrolled, electronic copy)

1 (Uncontrolled, electronic copy)

2 (Uncontrolled, electronic copies)

1 (Uncontrolled, electronic copy) 
CAU 107 Closure Report

Section: Library Distribution List

Revision: 0

Date: June 2009

THIS PAGE INTENTIONALLY LEFT BLANK 